\title{
DISCLAIMER
}

This report was prepared as an account of work sponsored by an agency of the United States Government. Neither the United States Government nor any agency thereof, nor any of their employees, makes any warranty, express or implied, or assumes any legal liability or responsibility for the accuracy, completeness, or usefulness of any information, apparatus, product, or process diselosed, or represents the $t$ its use would not infringe privately owned rights. Reference herein to any specific commercial product, process, or service by trade name, trademark, manufacturer, or otherwise does not necessarily constitute or imply its endorsement, recommendation, or favoring by the United States Government or any agency thereof. The views and opinions of authors expressed herein do not necessarily state or reflect those of the United States Government or any agency thereof.

\section{LYSIMETER STUDY OF COMMERCIAL REACTOR WASTE FORMS: WASTE FORM ACQUISITION CHARACTERIZATION AND FULL-SCALE LEACHING}

BNL 51613

UC-70

Contributors

George Arnold

Peter Colombo

Eena-Mai Franz

Paul D. Kalb

Robert M. Doty

Peter Kemeny

Robert M. Neilson, Jr.

September 1982

Revised February 1983

\section{PREPARED UNDER SUBCONTRACT WITH SAVANKAH RIVER LABORATORY FOR THE UNITED STATES DEPARTMENT OF ENERGY}

\author{
NUCLEAR WASTE RESEARCH GROUP \\ DEPARTMENT OF NUCLEAR ENERGY \\ BROOKHAVEN NATIONAL LABORATORY' \\ ASSOCIATED UNIVERSITIES, INC. \\ UPTON, LONG ISLAND, NEW YORK 11973
}

\author{
BROL KHAVEN NATIONAL LABORATORY \\ ASSOCIATED UNIVERSITIES, INC. \\ UPTON, LONG ISLAND, NEW YORK 11973
}




\section{SUMMARY}

This report describes work conducted at Brookhaven National Laboratory (BNL) as part of a joint program with Savannah River Laboratory (SRL) entitled, "Lysimeter Study of Commercial Reactor Waste Forms." This work is supported by the U.S. Department of EnergY's Low-Level Waste Management Program (LIWMP).

Typical full-scale (55-gallon drum size) waste forms were acquired by BNL from a boiling water reactor (BWR) and a pressurized water reactor (PWR). Liquid waste stream activity concentrations were analyzed by gamma spectroscopy. This information was used to determine the waste form activity inventory, providing the necessary source term for lysimeter and leaching experiments. Predominant radionuclides of interest include Co-60, Cs-137, Cs-134, and $\mathrm{Mn}-54$.

A full-scale leaching experiment was initiated by BNL encompassing four representative waste stream-solidification agent combinations. Waste streans tested include PWR evaporator concentrate (boric acid waste), BWR evaporator concentrate (sodium sulfate waste) and BWR evaporator concentrate plus ion exchange resins. Solidification agents include masonry cement, portland type III cement, and vinyl ester-styrene (Dow polymer). Analyses of leachates indicate measurable leach rates of Cs-137, Cs-134, and Co-60 from both BWR and PWR cement waste forms. The leach rates for both cesium isotopes in cement are at least two orders of magnitude greater than those for cobalt. Leachates from the BWR Dow polymer waste form include the same isotopes present in cement leachates, with the additon of Min-54. Cesium leach rates from the Dow polymer waste form are approximately one order of magnitude lower than from an equivalent cement waste form. The co-60 cumulative fraction release, however, is approximately three times greater for the Dow polymer waste form. 
SUMMARY.

1. INIRODUCTION. .......................................

2. WASTE FORM ACQUISITION. ............................. 3

2.1 Portland Type III Cement Waste Forms.................... 6

2.2 Vinyl Ester-Styrene Waste Forms...................... 8

2.3 Masonry Cement waste Forms........................... 9

3. WASTE FORM ACTIVITY INVENTORY .......................... 10

3.1 Waste Stream Analysis.............................. 10

3.2 Determination of Waste Form Activity Inventory ............. 10

4. FULL SCALE LEACHING EXPERIMENT........................... 16

4.1 Leaching Test Method............................. 16

4.1 .1 Introduction............................... 16

4.1.2 Experimental Procedure....................... 16

4.1 .3 Leachate Analysis............................ 18

4.2 Full Scale Leach Test Results......................... 18

APPENDIX A: WASTE STREAM ANALYSIS......................... A-1

APPENDIX B: FULITSCALE LEACHING FACILITY.................... B-1

APPENDIX $C$ : WASTE FORM DECANNING OPERATION.................... C-1 


\section{LIST OF TABLES}

Table No.

Page

2.1 Full-Scale waste Forms Acquired for This Program............. 4

2.2 Waste Form Identification code......................... 5

3.1 Waste Stream Activity Concentration..................... 12

3.2 Calculated Activity Contents Series 1 waste Forms (Portland

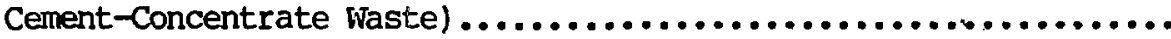

3.3 Calculated Activity Contents Series 2 Waste Forms (Portland Cement-Concentrate waste + Resin)

3.4 Calculated Activity Contents Series 4 Waste Forms (Masonry Cement-Boric Acid Concentrate).

3.5 Calculated Activity Contents Series 6 waste Forms (Vinyl Ester-Styrene - Concentrate Waste)

3.6 Calculated Activity Contents Series 7 waste Forms (Vinyl Ester-Styrene - Concentrate Waste + Resin)

4.1 Leachant Volume Data. 
Eigure No.

Page

4.1 Cumulative fraction release as a function of time for FWR evaporator concentrate waste in masonry cement (Waste Form $\$ 4-3$, Leach Tank $\$ 1$ )........................

4.2 Cumulative fraction release as a function of time for BWR evaporator concentrate waste in Dow polymer

(Waste Form \#6-3, Leach Tank \$2).

4.3 Cumulative fraction release as a funution of time for BWR evaporator concentrate + ion exchange resin waste in portland type III cement (Waste Form \$2-3, Leach risur. \$3)...

4.4 Cumulative fraction release as a function of time for BWR evaporator concentrate waste in portland type III cement (Waste Form \#1-3, Leach Tank \#4)

4.5 Incremental leach rate as a function of time for BWR evaporator concentrate waste in masonry cement (Waste Form \#4-3, Leach Tank \#1)

4.6 Incremental leach rate as a function of time for BWR evaporator concentrate waste in Dow polymer (Waste Form \#6-3, Leach Tank \$2)......................

4.7 Incremental leach rate as a function of time for BWR evaporator concentrate + ion exchange resin waste in portland type III cement (Waste Form \$2-3, Leach Tank \#3)

4.8 Incremental leach rate as a function of time for BWR evaporator concentrate waste in portland type III cement (Waste Form $\$ 1-3$, Leach Tank \$4) 


\section{INTRODUCTION}

The program, "Iysimeter Study of Commercial Reactor Waste Forms" is a cooperative program between Brookhaven National Laboratory (BNH) and Savannah River Laboratory (SRL) funded by the U.S. Department of EnergY's Low-Leve? Waste Management Frogram (LWWMP). BNL interacts under a subcontract from SFL who is the program contractor. The primary objectives of this program are:

(1) to determine the release rate for various radionuclides from full-size (55 gallon drum size) solidified reactor waste forms in shallow land burial,

(2) to investigate the partitioning of the released activity between percolate water and the soil with time, and

(3) to conduct a leaching experiment to determine the release rate of radionuclides from full-size solidified reactor waste forms in demineralized water.

Objectives 1 and 2 comprise the lysimeter testing phase of the program and will be performed at the Savannah River Plant (SRP) shallow land burial site. SRL will design, construct and operate the lysimeters. BNL is comitted to acquire and characterize solidified commercial reactor waste forms as well as perform the full-scale leaching experiment. Results from SRL soil lysimeter and BNL full-scale leaching experiments will be compared as SRL lysimeter data become available. Such a comparison will be useful in determining the potential of leaching experiments as a tool for predicting the release of radionuclides from full-scale waste forms in a shallow land burial enviromment.

This report describes Brookhaven National Laboratory's efforts in waste form acouisition, waste stream and waste form characterization and the full-scale leaching experiment. At present, the laching test is continuing. However, interim leaching data have been compiled and these results are included in this report. 
As the leaching of full-size solidified reactor waste forms is unique, several obstacles were encountered in conducting this experiment. These include: 1) techniques for determining the source term 2) the design and fabrication of the leaching facility, and 3) the handling and removal of waste forms from their containers. Detailed descriptions of the radiochemical aralyses, leaching facility and waste form decanning operation are therefore included in the text and appendices. 


\section{WASTE FORM ACQUISITION}

Negotiations were conducted with a number of utilities during FY 1981 to obtain their cooperation in the acquisition of a variety of waste types for this program. Some utilities declined on the basis of the time and manpower required together with little perceived benefit to the utility and, in some cases, the potential for possible difficulties with regulatory agencies and shallow land burial sites. The latter reason was of particular significance relative to efforts to obtain urea-formaldehyde waste forms. In any case, the use of urea-formaldehyde at commercial reactors declined dramatically during the last part of 1981 as a result of changes in SLB site waste package acceptance policies.

Two utilities did agree to cooperate in these efforts. A number of meetings and considerable direct contact was required however to acconplish the waste form acquisition. These discussions considered (1) the mechanism for obtaining and transporting waste forms, (2) the interface of waste containers and liners with station solidification equipment and (3) the use and reporting of the data obtained in these studies. The first two items will be considere' in later sections dealing with the acquisition of waste forms from the individual sites. BNL did agree (and SRL concurred) not to identify in published reports the reactor stations from which waste forms were obtained and to provide copies of published reports to these utilities and other cooperating parties.

Full-scale (55 gallon drum size) waste forms were acquired during FY 1982 from two reactor stations, identified as station A and Station B. Station A provided portland cement waste forms containing evaporator concentrate waste and evaporator concentrate + ion exchange resin waste and vinyl ester-styrene waste forms containing similar wastes. Station B provided masonry cement waste forms containing boric acid concentrate waste. The waste form types obtained are sumarized in Table 2.1. The waste form identification code is listed in Table 2.2. Three waste forms of each type (waste-solidification agent combination) were acquired from 
Table 2.1

Full-Scale waste Forms Acquired for this Program

Solidification Agent

Taste Type

Evaporator concentrate (regenerative) waste

Evaporator concentrate

(regenerative) + ion

exchange resin waste

Boric acid concentrate waste
Port land Type III cement

$$
\text { station } A^{(a)}
$$

Station A
Station A

\section{Masonry Cement}

\section{Station A}

Station ${ }_{B}{ }^{(b)}$

(a) 800 MWe BWR

(b) 830 MWe PWR 
Table 2.2

Waste Form Identification code

\begin{tabular}{|c|c|c|c|}
\hline $\begin{array}{c}\text { Waste Form } \\
\text { Identification } \\
\text { code }\end{array}$ & Waste Tyoe & $\begin{array}{l}\text { Solidification } \\
\text { Agent }\end{array}$ & $\begin{array}{c}\text { Aoguisition } \\
\text { Date }\end{array}$ \\
\hline $1-1,1-2,1-3$ & BWR Concentrate Waste & Portland Cement & $8 / 25 / 81$ \\
\hline $2-1,2-2,2-3$ & $\begin{array}{l}\text { BWR Concentrate Waste } \\
+ \text { Ion Exchange Resin }\end{array}$ & Portland Cement & $8 / 25 / 81$ \\
\hline $4-1,4-2,4-3$ & FWh Concentrate Waste & Masonry Cement & $1 / 23 / 82$ \\
\hline $6-1,6-2,6-3$ & BWR Concentrate Waste & Vinyl Ester-styrene & $11 / 17 / 81$ \\
\hline $7-1,7-2,7-3$ & $\begin{array}{l}\text { BWR Concentrate Waste } \\
+ \text { Ion Exchange Resin (a) }\end{array}$ & VinyI Ester-styrene & $11 / 17 / 81$ \\
\hline
\end{tabular}

(a) Lue to pump pluggage, resin was not added to $7-2$.

these commercial reactor stations by BN. Two of each type were shipped to SRL for lysimeter experiments while the remaining waste form of each type was shipped to ENL for full-scale leaching experiments.

Some other generalized considerations relating to waste form acquisition should be mentioned. The solidification equipment utilized at these reactor stations was not designed or specifically adapted to the needs of this program. It was designed to provide solidification of inplant waste and not necessarily well characterized, uniform waste form products. in addition, samples of the input waste stream were required to calculate the waste form activity inventory. However, at both sites 
special provisions had to be made to manually obtain the representative waste stream samples. The waste input into the solidification equipment should be uniform (and identical to the waste stream specimens). While mixing tanks were used to homogenize the waste, there was no ability to verify waste stream uniformity.

Similarly, the quantity of waste (and solidification agent) incorporated into each waste form was dependent upon installed transport and metering equipment, but was not directly verifiable. Reliance was placed upon the best operating techniques and information that could be provided by the reactor stations for the identified needs of this program. However, in spite of the difficulties encountered, in-plant operations were generally consistent with programmatic needs.

An additional limitation on the waste acquisition effort was imposed $b_{i}$ Savannah River Plant (SRP) personnel. SRP personnel were responsible for removing the containers and liners from waste forms to be employed in the lysimeters as well as the lysimeter placement operation itself. In order to limit the dose committment to SRP personnel, a maximum waste form contact dose limit of $3 \mathrm{Ren} / \mathrm{hr}$ was imposed. The effect of this contact dose limit was to restrict the quantity of ion exchange resin which could be incorporated in waste forms containing the evaporator concentrate + ion exchange resin waste.

\subsection{Portland Type III Cement Waste Forms.}

Portland type III cement waste forms containing evaporator concentrate (regenerative) waste and containing evaporator concentrate (regenerative) + ion exchange resin waste were produced at Station A on August 25, 1981. An installed Stock Equipment Company (SECO) end-over-end drum tumbler system was used to provide solidification.

The SFCo system employs closed head Dor 17C 55 gallon drums containing a special four inch diameter bunghole in the upper head sheet to permit insertion of a waste input nozzle. Acquisition of masonry cement and vinyl ester-styrene waste forms utilized a high density polyethylene 
Iiner (0.094 inch thick) inside the 55 gallon mild steel drum to facilitate removal of the waste form for lysimeter and leach testing. However, a liner could only be used with the SECo system if a reliable method could be found to prevent cement mix from entering the space between the liner and the drum during end-over-end tumbling. Despite significant efforts in this regard, no such reliable method was identified so a polyethylene liner was not used with portland type III cement waste forms. The consequences of not using a liner are described in Appendix $C$ where the removal of the waste form from its container is described.

Using the SECo system, the desired quantity of dry cement powder and a mixing weight (eight pound bent section of rebar) were placed into the 55 gallon drum in a "cold" area of the waste treatment facility. The drum was then transported to the drum tumbler where the drun bung was removed remotely, a measured quantity of waste added, the bung replaced and the drum tumbled for a specified time. This system employs two waste addition and tumbling operations. In the first, approximately 608 of the total waste quantity was added and the drum tumbled for six minutes. The remaining waste was then added to the drum which was tumbled an additional seven minutes. The drum was then removed from the soldification system and set aside to cure. A steel eyebolt approximately 18 inches long and fabricated from $3 / 8$ inch rebar was suspended in the cement mix before it had cured. This eyebolt was emplaced to facilitate subsequent waste form handling operations.

Prior to the solidification operation, the waste in the waste storage tank was mixed to promote uniformity. A sample of the waste was taken manually from the input line to the solidification system. While waste samples were to be taken for both wastes solidified with portland cerment, the evaporator concentrate + resin waste specimen was not obtained as requested. However, the activity content of this waste could be determined fram ocher waste specimens obtained from Station $A$ as described in section 3.2 . 


\subsection{Vinyl Ester-Styrene Waste Forms.}

Vinyl- ester-styrene waste forms containing evaporator concentrate (regenerative) waste and containing evaporator concentrate (regentrative) + ion exchange resin waste were produced at Station A on Noventer 17, 1981. This effort employed a mobile solidification system supplied by the Dow Chemical Company.

This system uses a high shear in-container mixing device with a reusable mixing biade. Waste was solidified in open head 55 gallon mild steel DOT 17C drums with a high density polyethylene drum line: 10.094 inch thick). The purpose of the liner was to facilitate subsequent waste form removai operations. The vinyl ester-styrene solidification agent uses a promoter/catalyst addition to promote polymerization at roan temperature.

After removing the drum head, the liner was inserted and the drum placed under the solidification equipment mixing head. All of the vinyl ester-styrene was placed into the drum before the addition of any waste. The desired quantity of waste was then added to the vinyl ester-styrene at a controlled rate under high shear mixing conditions. Water in the waste forms an emulsion with the vinyl ester-styrene under high shear mixing and, after polymerization, this water is trapped in a closed cell structure within the waste form. Waste solids are physically entrapped in the vinyl ester-styrene matrix. Temperature indicators were affixed to the outside of the waste form containers to verify, by indicating the occurrence of an exotherm, that polymerization of the vinyl ester-styrene had taken place. While eyebolts were supposed to have been emplaced in the vinyl ester-styrene waste forms to facilitate handling operations, this was not doi.e. Another technique, described in Appendix $\mathrm{C}$ was used for handling vinyl ester-styrene waste forms.

Samples of both waste types solidified were taken manually prior to the solidification operation. 


\subsection{Masonry Cement Waste Forms.}

Masonry cement waste forms containing boric acid concentrate waste were produced at Station B on January 23, 1982. Solidification was provided by an installed ATCOR in-line mixer system.

Masonry cement is a mixture of portland type I cement and slaked lime (on a $1: 1$ weight basis). Masonry cement is particularly useful for the solidification of wastes such as boric acid concentrate which retard the setting and curing of portland cement.

The ATCOR solidification system uses an in-line mixer to combine the waste with masonry cement powder. The output of the mixer is normally transferred into a large carbon steel liner for solidification. However, personnel at Station $B$ were able to provide a test stand which enabled the placement of a mild steel DOT 17C 55 galion drum against the output poit of the solidification system, A 0.094 inch thick high density polyethylene drum liner was placed into the drum prior to solidification. Waste and masonry cement were combined in the in-line mixer in a known ratio and the mixture discharged into the 55 gallon drum. Drum filling was continued until the cement-waste mix began to splatter from the arum. This enabled filling of the drum to about $2 / 3$ of its volume. Before the cement set, a steel eyebolt approximately 18 inches in length which was fabricated from $3 / 8$ inch rebar was emplaced in the mixture. The eyebolt was subsequently used to facilitate waste form handling operations.

Prior to solidification, the waste storage tank was mixed and samples of the boric acid concentrate waste obtained manually from the input line to the solidification system. Three individual one liter waste specimens were obtained. The first was described as unrepresentative since it partially contained material which was removed from the dead space in the waste transfer piping. 


\section{WASTE FORM ACTIVITY INVENIORY}

\subsection{Waste Stream Analysis.}

Liquid waste samples were processed and the ganma activity inventory was measured using a calibrated intrinsic germanium detector and a Tracor Northern-4000 analyzer computer. ${ }^{90}$ Sr concuntration was determined by radiochemical separation and analysis of its daughter product, ${ }^{90} \mathrm{y}$, using an anticoincidence low background beta counter.

The concentrations and percentages of the total activity of the major radioactive constituents found in the waste stream samples are listed in Table 3.1. In the case of ${ }^{144} \mathrm{Ce}$ a correction factor for absorption of the $133 \mathrm{keV}$ gamma ray in the solid fractions of the samples was applied.

The errors listed in Table 3.1 include counting statistics (which include errors in gamma spectra stripping) and a $10 \%$ error in the detector efficiency. For $\mathrm{Co}, \mathrm{Cs}$, and $\mathrm{Mn}$ isotopes, errors cue to counting statistics were 58 or less. For $\mathrm{Ce}, \mathrm{zn}$, and $\mathrm{Sb}$ the counting statistics ranged from $13 \%$ to $16 \%$. In the case of ${ }^{144} \mathrm{Ce}$, an error in the absorption factor was also included. The uncertainties in the ${ }^{90} \mathrm{Sr}$ analysis include counting statistics, uncertainties in the absolute counter efficiency and radiochemical and gravimetric yield determinations.

Traces of other radionuclides not listed in Table 3.1 could also te detected, but without extensive radiochemical separations of the various elements, their concentrations could not be determined with sufficient accuracy. It is not expected that these isotopes will be present in the leachates above detection limits.

\subsection{Determination of Waste Form Activity Inventory.}

The data determined for the activity concentration in the individual waste streams, together with the best information obtained from the power reactor stations concerning the solidification of these wastes, have been 
used to calculate the activity content of the full scale waste forms. These data are shown in Tables 3.2 through 3.6 for the individual waste forms from series 1, 2, 4, 6 and 7 respectively.

As discussed in Section 2.1, a sample of the BWR evaporator concentrate plus ion exchange resin waste (for series 2 portland type III cement waste forms) was not acquired as requested. The activity of these waste forms was calculated by proportionally surming the individual activities of equivalent compnents of other waste streams.

A detailed description of waste processing and analysis procedures is included in Appendix A. 
Table 3.1

Waste Stream Activity Concentration

Activity Concentratione uCi/liter (Corrected to date of acouisition)*

\begin{tabular}{|c|c|c|c|c|}
\hline & Os Series 1 & Ot Series 6 & Ol + Rseries I & BAC Series 4 \\
\hline${ }^{60} \mathrm{Co}$ & $\begin{array}{c}1.13 \times 10^{3} \pm 0.11 \times 10^{3} \\
(65.38)\end{array}$ & $\begin{array}{c}1.95 \times 10^{3} \pm 0.20 \times 10^{3} \\
(75.18)\end{array}$ & $\begin{array}{c}4.65 \times 10^{3} \pm 0.47 \times 10^{3} \\
(74.08)\end{array}$ & $\begin{array}{c}1.37 \times 10^{1} \pm 0.14 \times 10^{1} \\
(51.68)\end{array}$ \\
\hline${ }^{137} \mathrm{Cs}$ & $\begin{array}{c}3.51 \times 10^{2} \pm 0.35 \times 10^{2} \\
(20.38)\end{array}$ & $\begin{array}{c}3.23 \times 10^{2} \pm 0.32 \times 10^{2} \\
(12.48)\end{array}$ & $\begin{array}{c}7.69 \times 10^{2} \pm 0.77 \times 10^{2} \\
(12.28)\end{array}$ & $\begin{array}{c}6.74 \times 10^{0} \pm 0.67 \times 10^{0} \\
(25.48)\end{array}$ \\
\hline${ }^{134} \mathrm{cs}$ & $\begin{array}{c}7.96 \times 10^{1} \pm 0.80 \times 10^{1} \\
(4.68)\end{array}$ & $\begin{array}{c}7.80 \times 10^{1} \pm 0.78 \times 10^{1} \\
(3.08)\end{array}$ & $\frac{1.99 \times 10^{2} \pm 0.20 \times 10^{2}}{(3.28)}$ & $\begin{array}{c}3.01 \times 10^{0} \pm 0.30 \times 10^{0} \\
(11.38)\end{array}$ \\
\hline${ }^{144} \mathrm{Ce}$ & $\frac{2.71 \times 10^{1} \pm 0.40 \times 10^{1}}{(1.68)}$ & $\underbrace{4.62 \times 10^{1} \pm 0.69 \times 10^{1}}_{(1.88)}$ & $\frac{1.28 \times 10^{2} \pm 0.19 \times 10^{2}}{(2.08)}$ & - \\
\hline${ }^{54} \mathrm{Mn}$ & $\frac{1.06 \times 10^{2} \pm 0.11 \times 10^{2}}{(6.18)^{2}}$ & $\frac{1.56 \times 10^{2} \pm 0.16 \times 10^{2}}{(6.08)}$ & $\frac{4.15 \times 10^{2} \pm 0.42 \times 10^{2}}{(6.68)}$ & $\underset{(4.68)}{1.21 \times 10^{0} \pm 0.12 \times 10^{0}}$ \\
\hline${ }^{65} \mathrm{zn}$ & $\begin{array}{c}1.35 \times 10^{1} \pm 0.22 \times 10^{1} \\
(0.88)\end{array}$ & $\begin{array}{c}2.06 \times 10^{1} \pm 0.33 \times 10^{1} \\
(0.88)^{1}\end{array}$ & $\begin{array}{c}4.96 \times 10^{1} \pm 0.79 \times 10^{1} \\
(0.88)\end{array}$ & $\begin{array}{c}4.6 \times 10^{-2} \pm 0.6 \times 10^{-2} \\
(0.28)\end{array}$ \\
\hline${ }^{58} \mathrm{Co}$ & - & - & - & $\begin{array}{c}1.75 \times 10^{0} \pm 0.18 \times 10^{0} \\
(6.68)\end{array}$ \\
\hline${ }^{57} \mathrm{Co}$ & - & - & - & $\begin{array}{c}1.92 \times 10^{-2} \pm 0.19 \times 10^{-2} \\
(0.078)\end{array}$ \\
\hline${ }^{125} \mathrm{Sb}$ & - & - & - & $\begin{array}{c}9.1 \times 10^{-2} \pm 1.8 \times 10^{-2} \\
(0.38)\end{array}$ \\
\hline${ }^{90} \mathrm{Sx}$ & $\underset{(1.38)}{2.25 \times 10^{1} \pm 0.11 \times 10^{1}}$ & $\begin{array}{c}2.34 \times 10^{1} \pm 0.12 \times 10^{1} \\
(0.98)\end{array}$ & $\begin{array}{c}7.32 \times 10^{1} \pm 0.37 \times 10^{1} \\
(1.28)\end{array}$ & $\begin{array}{c}3.8 \times 10^{-3} \pm 0.6 \times 10^{-3} \\
(0.018)\end{array}$ \\
\hline $\begin{array}{l}\text { Total } \\
\text { Activity }\end{array}$ & $1.73 \times 10^{3}$ & $2.60 \times 10^{3}$ & $6.28 \times 10^{3}$ & $2.66 \times 10^{1}$ \\
\hline $\begin{array}{l}\text { ON Serie } \\
\text { ON Serie } \\
\text { ON + R S } \\
\text { BAC Seri }\end{array}$ & $\begin{array}{ll}\text { Is } 1 & =\text { BWR evapo } \\
\text { is } 6 & =\text { BWR evapo } \\
\text { eries } 7 & =\text { BWR evapo } \\
\text { es } 4 & =\text { FWR evapo }\end{array}$ & $\begin{array}{l}\text { concentrate waste } \\
\text { concentrate waste } \\
\text { concentrate }+ \text { ion } \\
\text { concentrate in mas }\end{array}$ & $\begin{array}{l}\text { ortland type III } \\
\text { polymer. } \\
\text { ange resin waste } \\
\text { cement. }\end{array}$ & \\
\hline
\end{tabular}

*percentage of the total activity for each isotope is given in parentheses. 
Table 3.2

Calculated Activity Contents Series 1 Waste Forms (Portland Cement-Concentrate Waste)

Activity Content, $\mathrm{MCi}$ (at acouistion)

Drum 1-1

${ }^{60} \mathrm{Co}$

${ }^{137} \mathrm{Cs}$

${ }^{134} \mathrm{Cs}$

${ }^{144} \mathrm{Ce}$

$54 \mathrm{Mn}$

${ }^{65} \mathrm{zn}$

${ }^{90} \mathrm{Sr}$

$1.39 \times 10^{5}$

$4.32 \times 10^{4}$

$9.79 \times 10^{3}$

$3.32 \times 10^{3}$

$1.30 \times 10^{4}$

$1.66 \times 10^{3}$

$2.77 \times 10^{3}$

Drum 1-2

Drum_1-3

$1.30 \times 10^{5}$

$4.05 \times 10^{4}$

$1.19 \times 10^{5}$

$9.18 \times 10^{3}$

$3.15 \times 10^{3}$

$1.22 \times 10^{4}$

$1.56 \times 10^{3}$

$3.71 \times 10^{4}$

$8.41 \times 10^{3}$

$2.88 \times 10^{3}$

$1.12 \times 10^{4}$

$1.43 \times 10^{3}$

$2.36 \times 10^{3}$

Table 3.3

Calculated Activity Contents Series 2 waste Forms (Portland Cement - Concentrate Waste + Resin)

Activity Content, $\mu \mathrm{Ci}$ (at acouistion)

Drum 2-1

${ }^{60} \mathrm{Co}$

${ }^{137} \mathrm{Cs}$

${ }^{134} \mathrm{Cs}$

${ }^{144} \mathrm{Ce}$

$54_{\mathrm{Mn}}$

$65_{\mathrm{zn}}$

${ }^{90} \mathrm{Sr}$
Drum 2-2

$4.40 \times 10^{5}$

$9.16 \times 10^{4}$

$2.31 \times 10^{4}$

$1.25 \times 10^{4}$

$4.19 \times 10^{4}$

$4.91 \times 10^{3}$

$8.31 \times 10^{3}$
Drum 2-3

$4.42 \times 10^{5}$

$9.19 \times 10^{4}$

$2.32 \times 10^{4}$

$1.26 \times 10^{4}$

$4.21 \times 10^{4}$

$4.92 \times 10^{3}$

$8.34 \times 10^{3}$ 
Table 3.4

Calculated Activity Contents Series 4 Waste Forms (Masonry Cement-Boric Acid Concentrate)

$\begin{array}{lc} & \text { Activity Content, } \mu \mathrm{Ci} \text { (at acoluistion } \\ { }^{60} \mathrm{Co} & \text { Drum } 4-1,4-2,4-3 \\ { }^{137} \mathrm{Cs} & 8.85 \times 10^{2} \\ { }^{134} \mathrm{Cs} & 4.35 \times 10^{2} \\ { }^{54} \mathrm{Mn} & 1.94 \times 10^{2} \\ { }^{65} \mathrm{Zn} & 7.82 \times 10^{1} \\ { }^{125} \mathrm{Sb} & 2.97 \times 10^{0} \\ { }^{58} \mathrm{Co} & 5.88 \times 10^{0} \\ { }^{57} \mathrm{Co} & 1.13 \times 10^{2} \\ { }^{125} \mathrm{Sb} & 1.24 \times 10^{0} \\ 90 & 5.88 \times 10^{0} \\ 90 & 2.47 \times 10^{-1}\end{array}$

Table 3.5

Calculated Activity Contents Series 6 Waste Fonns (Vinyl Ester-Styrene - Concentrate Waste)

Activity Content. uCi (at acopuistion)

Drum 6-7, 6-2, 6-3

${ }^{60} \mathrm{Co}$

$1.96 \times 10^{5}$

${ }^{137} \mathrm{Cs}$

$3.24 \times 10^{4}$

${ }^{134} \mathrm{Cs}$

$7.82 \times 10^{3}$

${ }^{144} \mathrm{Ce}$

$4.62 \times 10^{3}$

$54 \mathrm{Mn}$

$1.56 \times 10^{4}$

$65 \mathrm{zn}$

$2.05 \times 10^{3}$

${ }^{90} \mathrm{Sr}$

$2.36 \times 10^{3}$ 
Table 3.6

Calculated Activity Contents Series 7 waste Forms (a)
(Vinyl Ester Styrene-Concentrate Waste + Resin)

Activity Content. $\mu$ Ci (at acouistion)

Drum 7-2

Drums $7-1,7-3$

$\begin{array}{lll}{ }^{60} \mathrm{Co} & 1.96 \times 10^{5} & 4.66 \times 10^{5} \\ { }^{137} \mathrm{Cs} & 3.24 \times 10^{4} & 7.71 \times 10^{4} \\ { }^{134} \mathrm{Cs} & 7.82 \times 10^{3} & 2.00 \times 10^{4} \\ { }^{144} \mathrm{Ce} & 4.62 \times 10^{3} & 1.28 \times 10^{4} \\ { }^{54} \mathrm{Fm} & 1.56 \times 10^{4} & 4.16 \times 10^{4} \\ { }^{65} \mathrm{Zn} & 2.05 \times 10^{3} & 4.97 \times 10^{3} \\ { }^{90} \mathrm{Sr} & 3.09 \times 10^{3} & 7.32 \times 10^{3}\end{array}$

(a) Due to pump blockage during preparation, drum 7-2 does not contain any ion exchange resin. 


\section{FULL SCALE LEACIING EXXERIMENT}

\subsection{Leaching Test Method.}

\subsubsection{Introduction.}

The majority of existing experimental data characterizing the leaching properties of solidified radicactive waste has been generated through the study of simulated laboratory scale specimens. Attempts have been made to standardize the methods used in conducting these leaching experiments so that results obtained may be evaluated on a common basis. The ANS 16.1 proposed standard "Measurement of the Leachability of Solidified Low-Level Radioactive Wastes" is one such attempt which has been gaining widespread acceptance [1]. As one of the objectives of the full scale leaching experiment is the comparison of results with those from small scale laboratory leach tests, the leaching procedure selected was modeled on the ANS 16.1 test. Die to the size and mass of full scalf waste forms some modifications in the procecures were necessary, the details of which are elaborated below.

\subsubsection{Experimental Procedurs.}

The leachant employed is demineralized water with an electrical conductivity of less than $5 \mu \mathrm{mho} / \mathrm{cm}$ at $25^{\circ} \mathrm{C}$ (equivalent to $>0.2$ megohm resistivity) and a total organic carbon content (TOC) of less than 3 ppm. The test was conducted at ambient room temperature which is $22 \pm 2{ }^{\circ} \mathrm{C}$.

The amount of leachant is specified in the ANS 16.1 test such that the ratio of leachant volume to the external geometric surface area of the waste form $\left(V_{L} / S\right)$ is equal to $10 \pm 0.2 \mathrm{~cm}$. Due to irregularities in the geometries of some of the waste forms, use of the leachant volumes specified by this ratio resulted in insufficient leachant to cover the entire surface area of the specimens. Additional leachant was added until the entire waste form was immersed in leachant. Thus the actual $\mathrm{V} / \mathrm{L}$ ratios ranged from $10.7 \mathrm{~cm}$ to $17.0 \mathrm{~cm}$. Leachant volume data is reported in Table 4.1. 
Table 4.1 Leachant Volume Data

\begin{tabular}{|c|c|c|c|c|}
\hline TANK $\neq$ & WASTE EORM : & $\begin{array}{c}\text { SURFACE AREA, } \\
\mathrm{cm}^{2} \\
\end{array}$ & $\begin{array}{c}\text { LEACHANT VOLUME } \\
\text { liters }\end{array}$ & $\underset{\mathrm{L}}{\mathrm{V} / \mathrm{S}}$ \\
\hline 1 & $4-3$ & 14130 & 240 & 17.0 \\
\hline 2 & $6-3$ & 15187 & 162 & 10.7 \\
\hline 3 & $2-3$ & 15847 & 240 & 15.1 \\
\hline 4 & $1-3$ & 16862 & 216 & 12.8 \\
\hline
\end{tabular}

According to the ANS 16.1 proposed standard, the $\mathrm{V}_{\mathrm{L}} / \mathrm{S}$ ratio of $10 \mathrm{~cm}$ was chosen to provide a sufficient volume of leachant to minimize potential leachant composition changes while still maintaining sufficient concentrations of extracted species for analysis. By employing an increased $\mathrm{v}_{\mathrm{L}} / \mathrm{s}$, only the latter consideration is of concern. Detection of those isotopes present in the leachettes in low concentrations was enhanced by employing large counting aliquots $(100 \mathrm{ml})$ and longer counting times (up to 400 minutes). These techniques provided adequate detection of all isotopes in the range of cumulative fraction releases greater than $10^{-5}$. Therefore, no adverse effects on experimental results are predicted by the use of increased $\mathrm{v}_{\mathrm{L}} / \mathrm{s}$ ratios.

At the end of each leaching interval, a $250 \mathrm{ml}$ aliquot was removed by means of the remote sampling system (described in Appendix B) for analysis ky gamma spectroscopy. Pricr to sampling, the leachate was recirculated for a period of 5 minutes to obtain a more homogeneous aliquot.

The leachate was then removed by draining the leach tank. The tank was refilled immediately with fresh demineralized water leachant. Leachant was renewed at the prescribed cumulative leach times of 2, 7, and 24 hours, and once each day for the next three days. In addition, leachant was replaced at 7,10 , and 15 days, once each week for 6 weeks and once every other week thereafter, to date. Leachant samplings are scheduled to continue for a total cumulative leach time of one year. 
The extension of the leaching period beyond the time recomnended in the ANS 16.1 test will provide information to better characterize the long term leaching behavior of actual power reactor waste forms.

The ANS 16.1 leaching procedure calls for an initial rinse with d full volume of leachant for 30 seconds to remove activity loosely held at the surface. Because of the time required to fill. and drain the fullscale leaching tanks, the rinse procedure as specified was not possible and was omitted. In previous laboratory scale leaching experiments involving similar solidification media, no activity could be detected in 30 second interval leachates [2]. The effect of onitting this procedure is judged to be insignificant.

\subsubsection{Leachate Analysis.}

Leachate samples were prepared for gamma counting by placing a $100 \mathrm{ml}$ aliquot in a polyethylene standard couriting bottle. Samples were acidified by the addition of $2 \mathrm{ml}$ of concentrated nitric acid. Replicate aliquots were prepared for some leachate samples by centrifuging and acidifying to determine if any partitioning of activity between dissolved and undissolved portions existed. Results indicated that little or no activity was associated with particulates in the leachate. Leachate counting analysis was performed by gamma spectroscopy as described in Section 3.1.

\subsection{Full-Scale Leach Test Results.}

Full-scale leach test results to date are shown in Figures 4.14.8. Data are shown indicating both cumulative fraction activity releases and incremental fraction release rates for individual radionuclides. The cumulative fraction activity release $\left(\sum \mathrm{a}_{\mathrm{r}} / \mathrm{A}_{\mathrm{o}}\right)$ for a given total leach time is the sum of the individual incremental releases $\left(\sum a_{n}\right)$ for each of the previous leach intervals divided by the initial activity present $\left(A_{0}\right)$ in the waste form for the radionuclide under consideration. The incremental activity release rate is determined by dividing the fraction activity released during a given leach interval $\left(a_{n} / A_{0}\right)$ by the duration of that leach interval (days). 


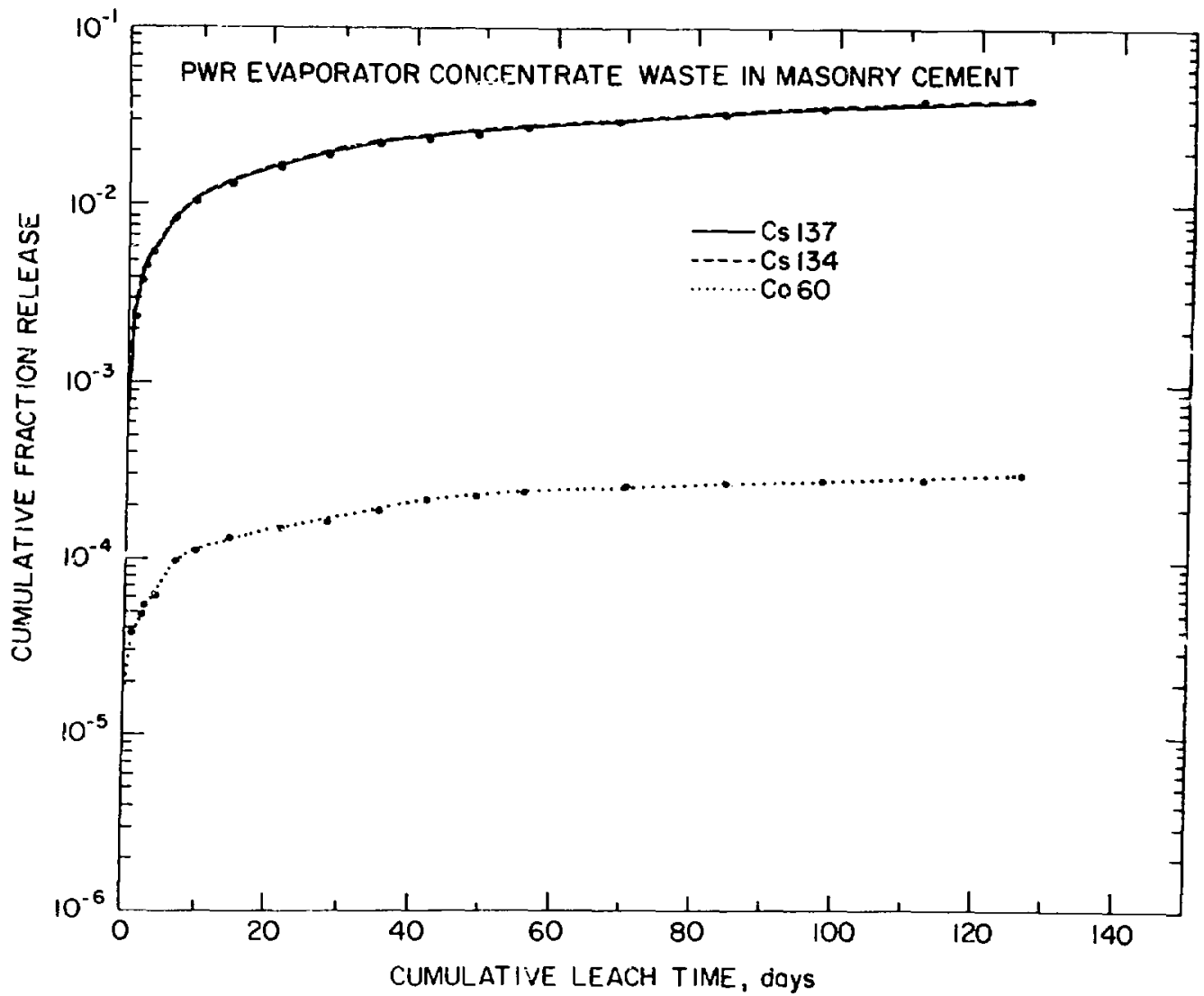

Fig. 4.1 Cumulative fraction release as a function of time for FWR evaporator concentrate waste in masonry cement (Waste Form \$4-3, Leach Tank \$1). 


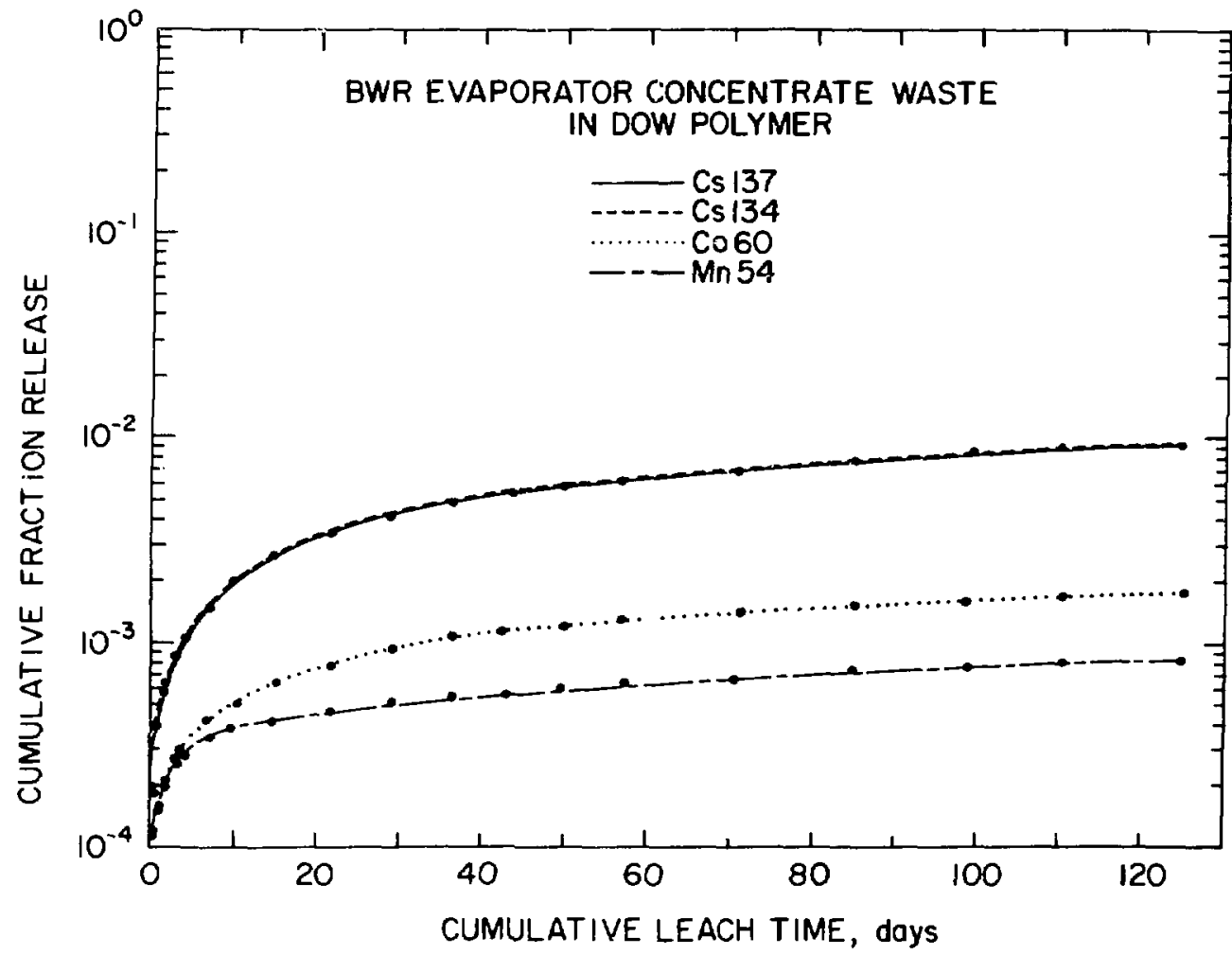

Fig. 4.2 Cumulative fraction release as a function of time for BWR evaporator concentrate waste in Dow polymer (Waste Form $\$ 6-3$, Leach Tank $\$ 2$ ). 


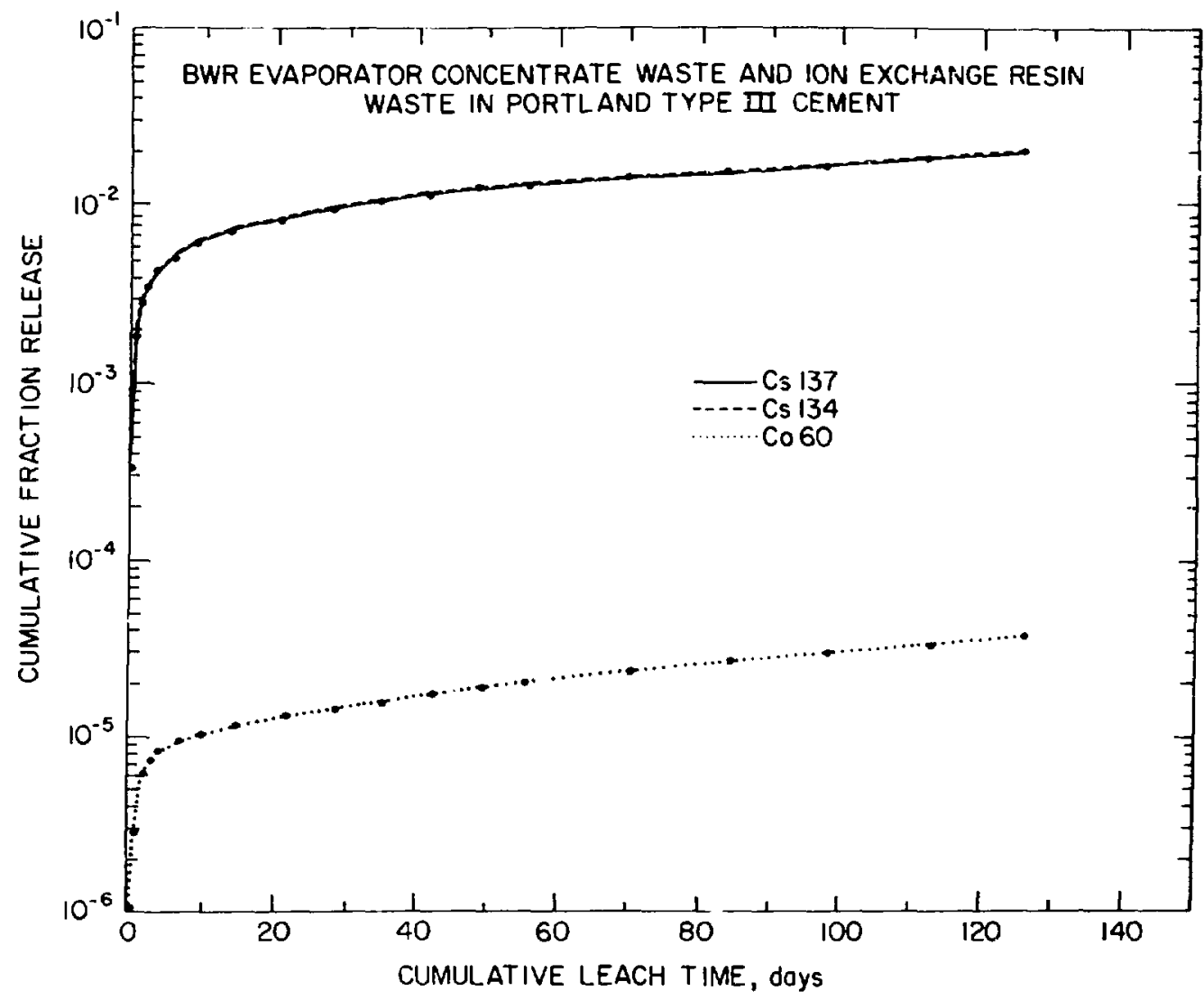

Fig. 4.3 Cumulative fraction release as a function of time for BWR evaporator concentrate + ion exchange resin waste in portland type III cement (Waste Form \#2-3, Leach Tank \#3). 


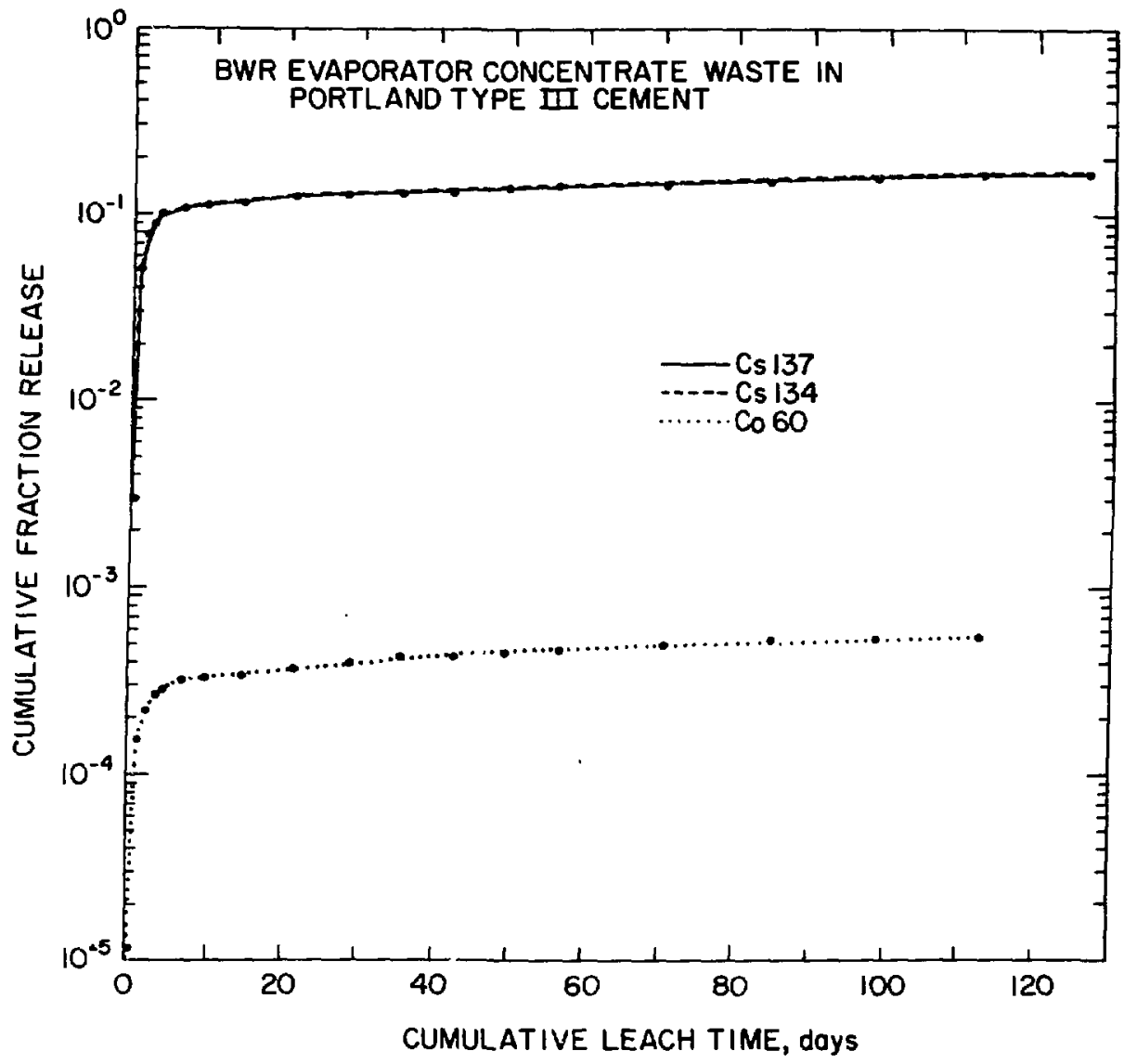

Fig. 4.4 Cumulative fraction release as a function of time for BWR evaporator concentrate waste in portland type III cement (Waste Form $\$ 1-3$, Leach Tank 4 ). 


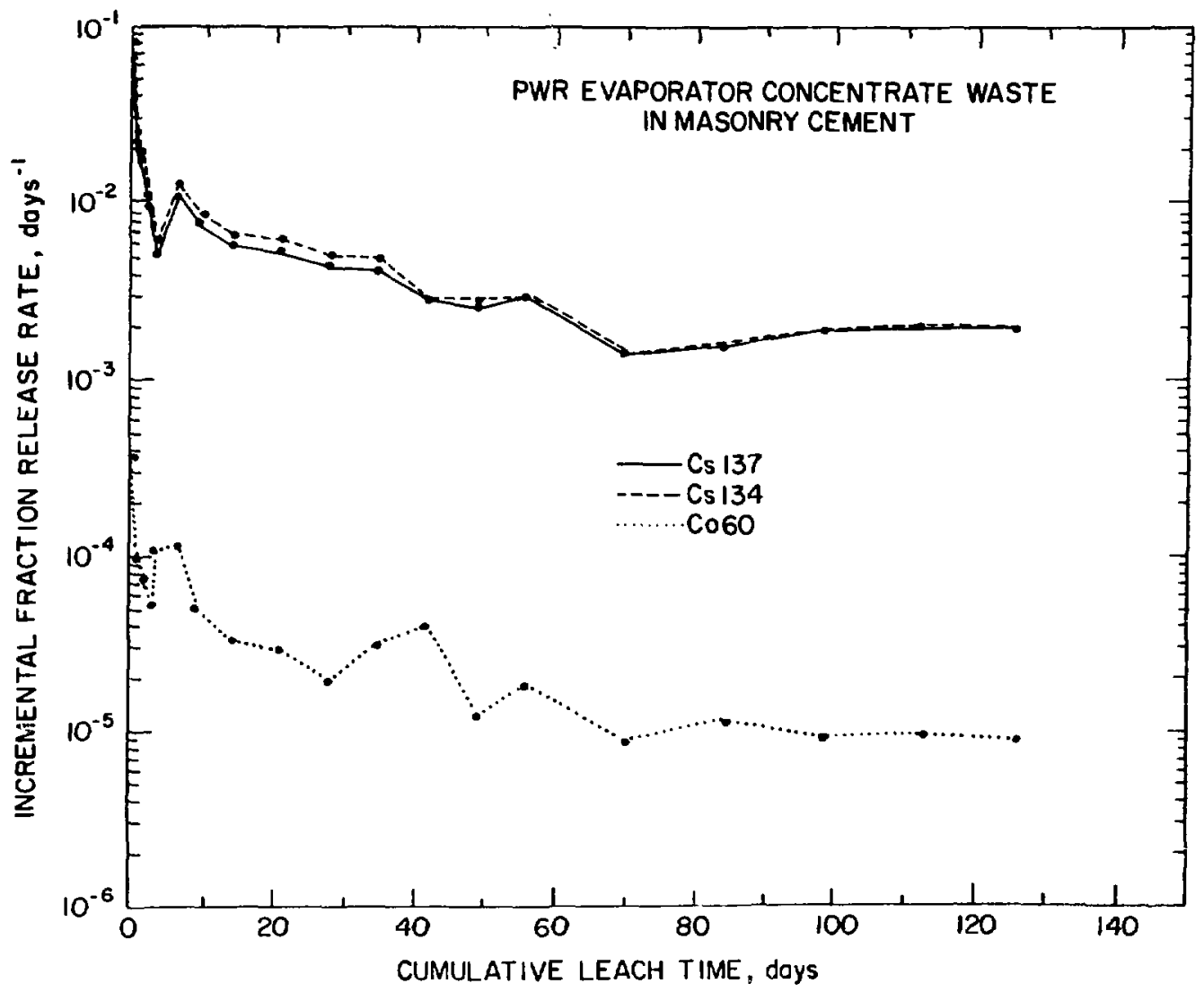

Fig. 4.5 Incremental leach rate as a function of time for BWR evaporator concentrate waste in masonry cement (Waste Form \$4-3, Leach Tank \$1). 


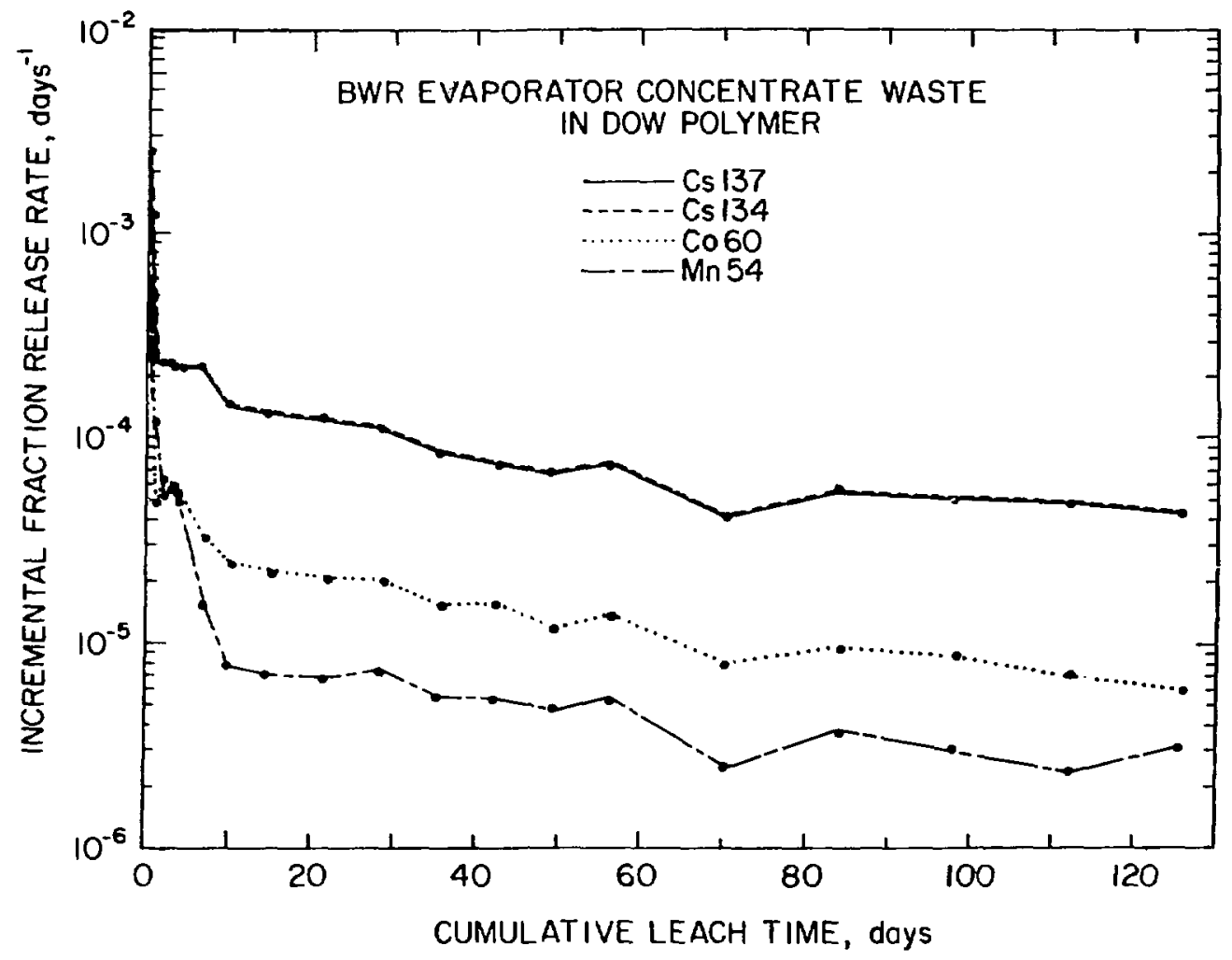

Fig. 4.6 Incremental leach rate as a function of time for BWR evaporator concentrate waste in Dow polymer (Waste Form *6-3, Leach Tank *2). 


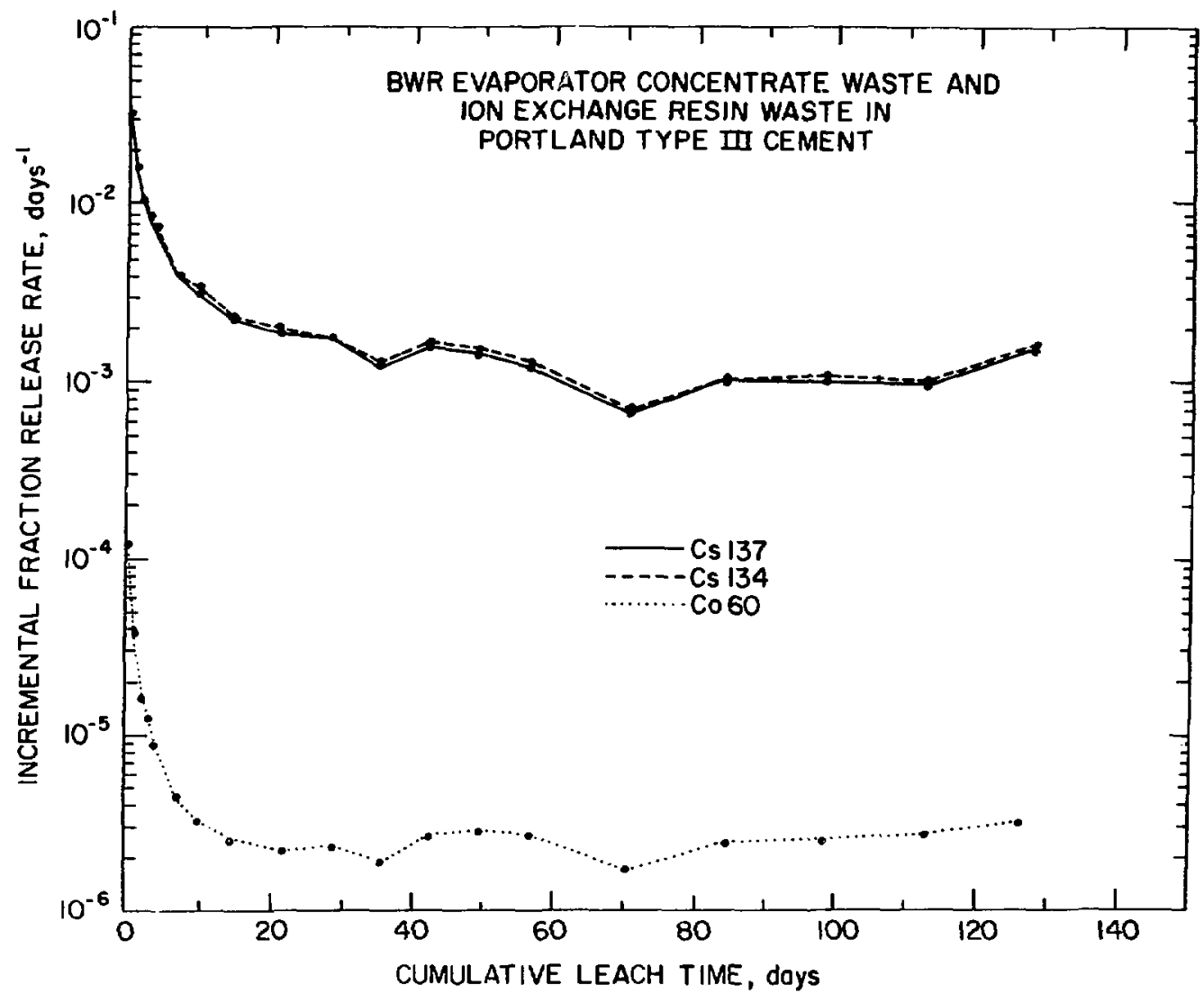

Fig. 4.7 Incremental leach rate as a function of time for BWR evaporator concentrate + ion exchange resin waste in portland type III cement (Waste Form \#2-3, Leach Tank $\$ 3$ ). 


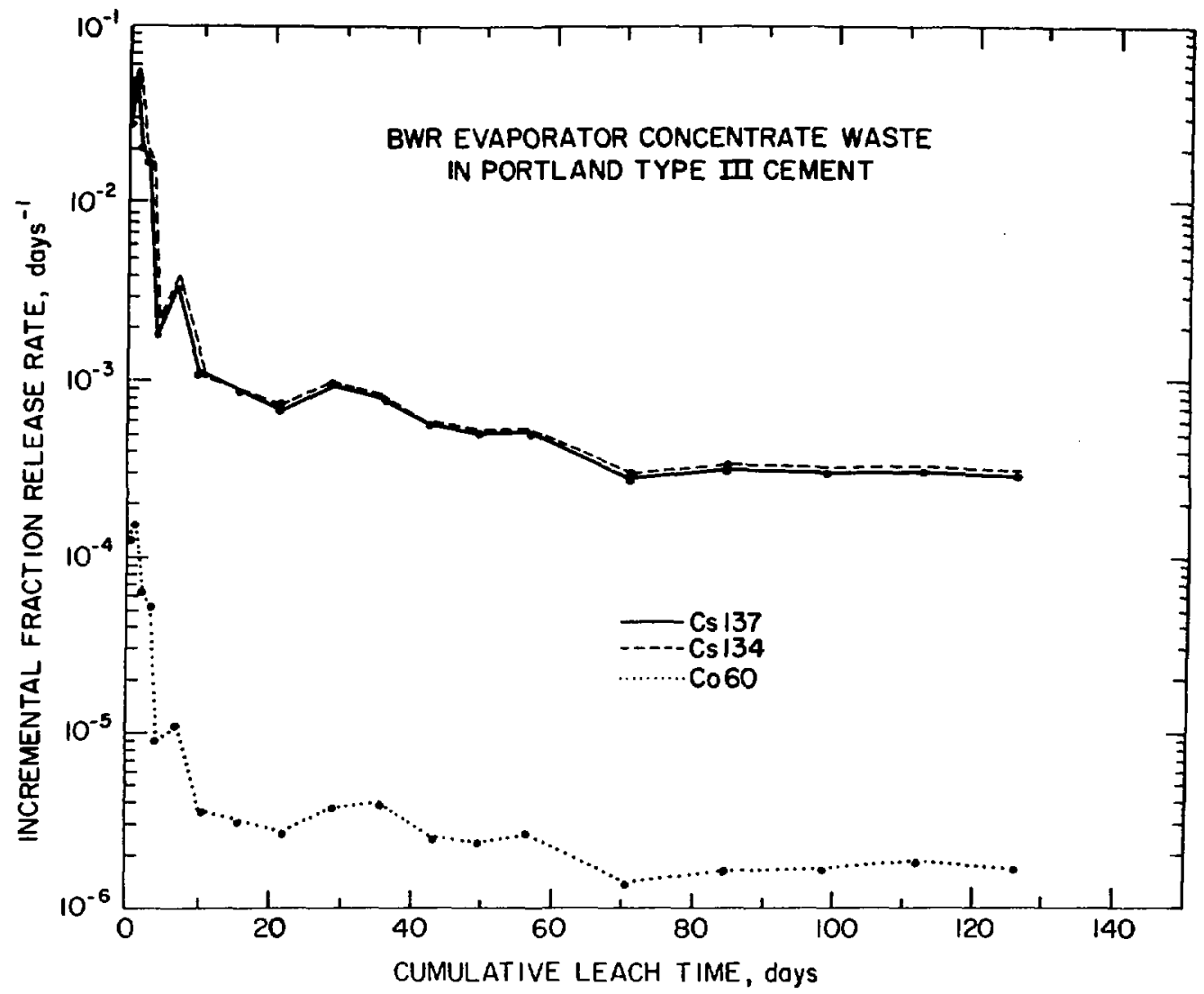

Fig. 4.8 Incremental leach rate as a function of time for BWR evaporator concentrate waste in portland type III cement (Waste Form \#1-3, Leach Tank *4). 
The data indicate measurable leach rates for Cs-137, Cs-134, and Co60 from both BWR and PWR cement waste forms. The leach rates for both cesium isotopes in cement are similar, as expected, and are at least two orders of magnitude greater than those of cobalt. Previous laboratoryscale leaching studies utilizing simulated waste [2] have shown similar relationships in the leachability of these isotopes. The extremely low leachability of Co-60 is attributed to its chemical interaction within the cement matrix and the resultant formation of compounds of low solubility.

Leachates from the BWR vinyl ester-stryene waste form (Dow polymer) include the same isotopes as those present in cement leachates, with the addition of Mn-54. Leachability from the vinyl ester-styrene waste form was less element dependent than from cement waste forms, i.e., there was just over one order of magnitude difference separating isotopes displaying the greatest and least cumulative fraction release. This can be attributed to the fact that, unlike cement, the Dow polymer system does not chemically combine with the incorporated waste. During the solidification process, an emulsion is formed between the waste and binder which, upon curing, physically encapsulates the waste and retards leachability. Cesium leach rates from the Dow polymer waste form are approximately one order of magnitude lower than from an equivalent cement waste form. The Co-60 cumulatitive fraction release, however, is approximately 3 times greater for the Dow than for cement. Again, this difference is attributed to the different methods of waste encapsulation in the two waste forms.

Not all of the radionuclides present in each waste form (as listed in Tables 3.2-3.6) are indicated in the leaching data. The radionuclides for which leaching data are not shown were not present in the leachate above detection limits (for reasonable counting times). This may be due to low leach rates, small initial concentration in the waste forms, or a combination of these factors. For those isotopes which were not detected in the leachate, but which are present in the source term $i_{1}$ an abundance approximately equivalent to the least abundant isotope measured in the leachate, a low leach rate can be assumed. For example, the BNR Series 1 
concentrate waste contains $6.18 \mathrm{Mn}-54(106 \mu \mathrm{Ci} / \mathrm{liter})$ compared with 4.68 Cs-134 (80 $\mu \mathrm{Ci} /$ liter). As seen in Figure 4.4, the cumulative fraction release of Cs-134 in portland type III cement was quite high $\left(>10^{-1}\right.$ after 7 days), while Mn-54 was not detected in the leachate. Based on this information, it is evident that the cumulative fraction release for Mn-54 in portland type III cement is less than $1 \times 10^{-5}$ (gamma counting detection limits for Mn-54). For those isotopes present in the waste in lower concentrations than cs-134 (4.68) e.g., Ce-144 (1.68) and $\mathrm{zn}-65$ $(0.88)$, there is insufficient evidence to make an absolute determination as to the cause of low leachability.

It should be noted that Sr-90 analysis of leachates (which requires radiochemical separation and use of an anticoincidence low background beta detector) has not been completed to date. Thus, Sr-90 fraction release data have not been compiled. 


\section{REFERENCES}

1. American Nuclear Society, Measurement of the Ieachability of Solidified Ion-Ievel Radioactive Wastes, Second Draft of a Standard, American Nuclear Society Standards Committee Working Group, ANS-16.1, April, 1981.

2. Neilson, R.M. Jr., and P. Colombo, Solidification of Ion Exchange Resin Wastes, BNL-51615, Brookhaven National Laboratory, Upton, NY, August 1982. 


\section{DISCLAIMER}

This report was prepared as an account of work sponsored by an agency of the United States Government. Neither the I nited States Government nor any agency thereof, nor any of their employees, nor any of their contractors, subcontractors, or their employees, makes any warranty, express or implied, or assumes any legal liability or responsibility for the accuracy, completeness, or usefulness of any infornation. apparatus, product, or process disclosed, or represents that its use would not infringe privately owned rights. Reference herein to any specific commercial product, process, or service by trade name, trademark, manufacturer, or otherwise, does not necessarily constitute or imply its endorsement, recommenda tion, or favoring by the Inited States Government or any agency, contractor or subcontractor thereof. The views and opinions of authors expressed herein do not necessarily state or reflect those of the lnited States Government or any agency. contracior or subcontractor thereof.

Printed in the United States of America Available from

National Technical Information Service

U.S. Department of Commerce

5285 Port Royal Road

Springfield, VA 22161

NTIS price codes:

Printed Copy: A04; Microfiche Copy: A01 


\section{APPENDIX A. WASTE STREAM ANALYSES}

\section{Introduction.}

The waste stream samples were contained in one liter polyethylene bottles. The BWR concentrate waste from series 1 and 6 waste forms consisted of a dark brown thick sludge, which occupied about a third of the waste volume, and a colorless liquid. Same ion exchange resin particles could be seen in the sludge. The samples were shaken and transferred with known amounts of demineralized water into large beakers where they were further stirred to facilitate representative sampling. Fifty milliliter aliquots were withdrawn with plastic pipettes and weighed.

The series 7 sample of BWR concentrate waste plus ion exchange resin, contained a smaller sludge fraction and more solution. Because of its smaller insoluble solids content, it was possible to sample it directly fron the original bottle after considerable shaking.

Series 4 waste, which is a IWR boric acid concentrate waste, also consisted of a solid and liquid phase. The white crystalline solid occupied about two thirds of the waste volume. It was sumised that the crystalline solid formed after the heated waste solution was transferred from the evaporator to the solidification system and allowed to cool in the sample bottle. At room temperature the waste sample was supersaturated with boric acid salts. Upon heating the waste in a hot bath at $97^{\circ} \mathrm{C}$ for about two hours, the crystalline solid went into solution. One hundred milliliters of the waste solution was then removed for analysis.

\section{Sample Processing.}

Station A: In an attempt to dissolve the brown sludge, duplicate waste samples from waste series, 1,6 and 7 were first digested in fuming $\mathrm{HNO}_{3}$ and later in both concentrated $\mathrm{ENO}_{3}$ and concentrated $\mathrm{HCl}$ for several days. The supernate was periodically removed from the solids as activity was being leached out. Depending on the sample, 5-20 ml of off-white 
insoluble solids remained. An aliquot of the supernate was taken for gamma counting and ${ }^{90} \mathrm{Sr}$ radiochemical analysis. The remaining solids were gamma counted separately. In order to determine whether any ${ }^{90} \mathrm{Sr}$ remained in the insoluble fractions, the solids from series 6 and 7 waste specimens were further processed in order to get them into solution.

The dissolution of the off-white solid fraction was accomplished by fuming with concentrated $\mathrm{H}_{2} \mathrm{SO}_{4}$, concentrated $\mathrm{HF}$, and concentrated $\mathrm{HNO}_{3}$ and dissolving the resulting residue in hot $\mathrm{HCl}$. Since ${ }^{90} \mathrm{Sr}$ was not found in the two samples thus processed it was assumed that Sr also would not be present in the solid fractions of waste samples from series $I$ and therefore it was considered unnecessary to further process series 1 wastes.

Station B: The $100 \mathrm{ml}$ representative sample taken of the boric acid waste was diluted with $400 \mathrm{ml}$ of $1 \mathrm{~N} \mathrm{HCl}$ to keep the waste in solution after it cooled. Aliquots of the solution were taken for ${ }^{90} \mathrm{Sr}$ radiochemical analysis and gamma counting.

\section{Gamma Spectroscopy.}

The gamma activity of known volumes of the samples, whether in solution or as solids, was measured with a calibrated intrinsic germanium detector and a Tracor Northern-4000 anlayzer computer system. The detector had been calibrated with standards obtained from the National Bureau of Standards.

As mentioned previously, the solid and liquid fractions of the samples were counted separately and in the final calculations the gamma counting data of all the fractions of each sample were combined to determine the total activity inventory in the waste sample. With the exception of ${ }^{144} \mathrm{Ce}$, only a small amount of the total activity of the prominent gamma-emitting radionuclides was found in the solid fraction. In order to determine the absorption of the low energy ( $133 \mathrm{keV}$ ) gamma ray of ${ }^{144} \mathrm{Ce}$ in the solid fraction, its counting data was compared to that of the same sample in the liquid phase after its dissolution. 
As described previously, great care was taken in the sampling process of Staticn A (BWR) waste samples to assure good mixing of the liquid and solid phases so that representative aliquots could be taken for analysis. The resulting success in sampling is supported by the fact that the final activity concentration of the duplicate samples agreed within 2-68 of each other for most isotopes. In the case of ${ }^{65} \mathrm{Zn}$ and ${ }^{144} \mathrm{Ce}$, the agreement ranged from 38 and 228.

\section{${ }^{90}$ Sr Analysis.}

A standard radiochemical procedure [1] was adapted for the separation and purification of $\mathrm{Sr} .{ }^{90} \mathrm{Sr}$ was separated from its daughter activity, ${ }^{90} \mathrm{Y}$, by an extraction with di-2-ethylhexyl phosphoric acid (HDEHP) and the final ${ }^{90} \mathrm{Sr}$ activity was calculated from the decay of the milked $90 \mathrm{Y}$. The ${ }^{90} \mathrm{Y}$ was counted using an anticoincidence low background beta counter and ${ }^{85} \mathrm{Sr}$ tracer was used to determine the Sr chemical yield. A gravimetric method was used to determine the chemical yield of yttrium.

The results of all waste stream analyses are summarized in section 3. Waste Form Activity Inventory. 
Appendix A. REFEREACES

1. Butler, F.E., Health Physics, 8, 273, (1962). 


\section{APPENDIX B. FULL SCALE LEACHING FACILITY}

\section{Introduction.}

An area of the BNL Hot Laboratory (Building 801) was modified to form the full-scale leaching facility. This location provided several advantages including availability of a shielded works area and access to the building's hot waste drains and large capacity liquid waste holdup tanks. The leaching facility consists of two rooms: the leaching cell and a control room.

The interior of the leaching cell measures 12 feet in length $x$ 6.5 feet in width and is 7.5 feet high. Adjacent to the cell is the control room, measuring 5.5 feet $\times 5.5$ feet $\times 7.5$ feet high. Views of the interior of the leaching cell and control room can be seen in Figures B.l and B.2. The walls of the leaching facility are 12 inch thick concrete. The southern exterior wall and the area between the leaching cell and the control room are lined with an additional 16 inch thick concrete brick to provide additional radiation shielding. The access doors for the cell are three inch thick steel. The interior of the leaching cell can be viewed through a twelve inch thick marine window. The facility is maintained under a small negative pressure with exhaust air passed through a high efficiency particulate air (HEPA) filter. The layout of the full-scale leaching facility is shown in Figure B.3.

Rijliation dose levels for the full-scale waste forms are sufficiently high to present a potential exposure hazard to operating personnel with substantial exposure times. It was decided, therefore, to design the facility to be operated and monitored remotely. This required that filling, sampling and draining operations as well as the monitoring of liquid levels be accomplished without close or direct contact with the waste form tanks. A more detailed description of the systen components follows. 


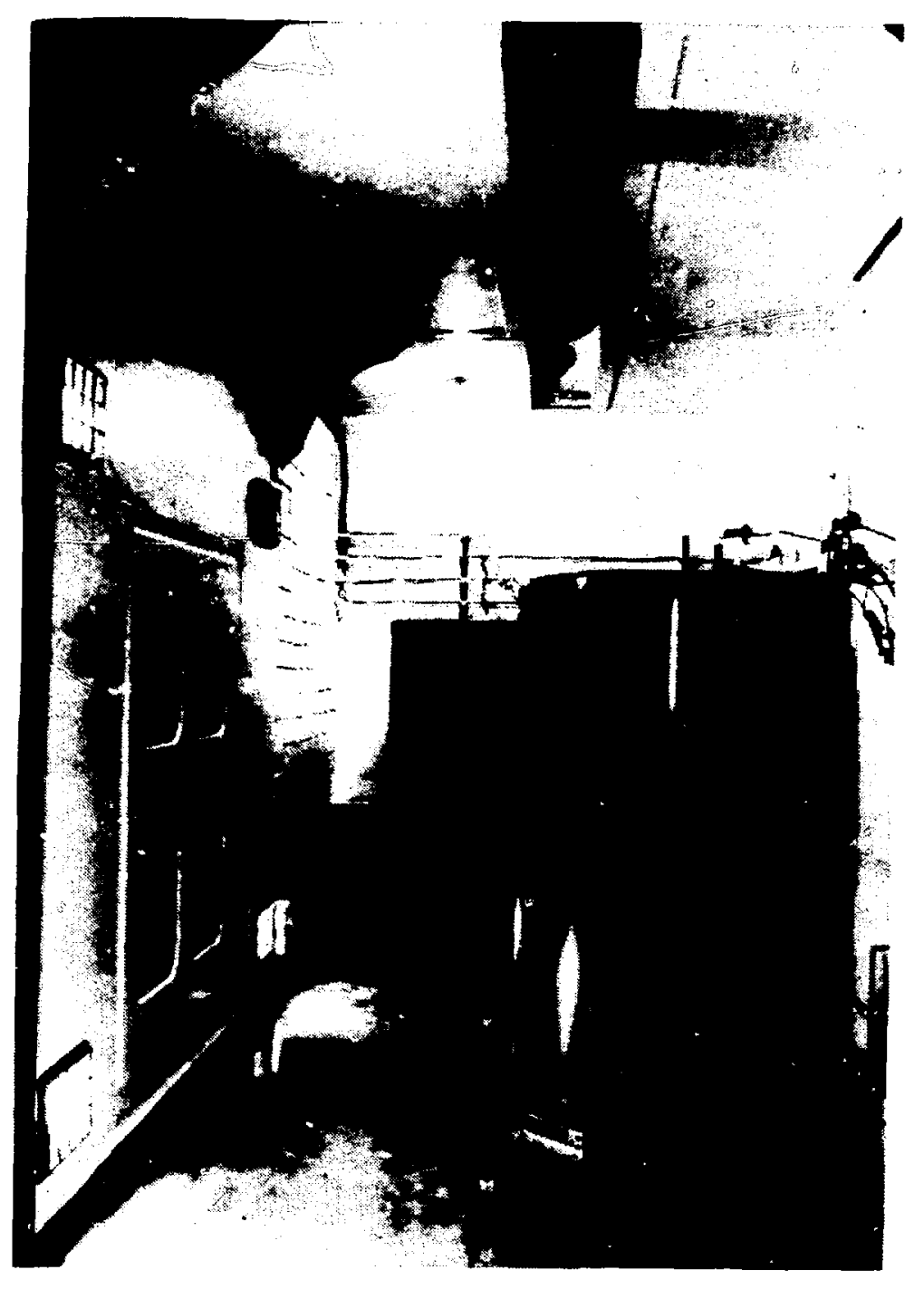

Fig. B.1 View of the inside of the Full Scale Leaching Cell. Note the marine window along the left-hand wall. 


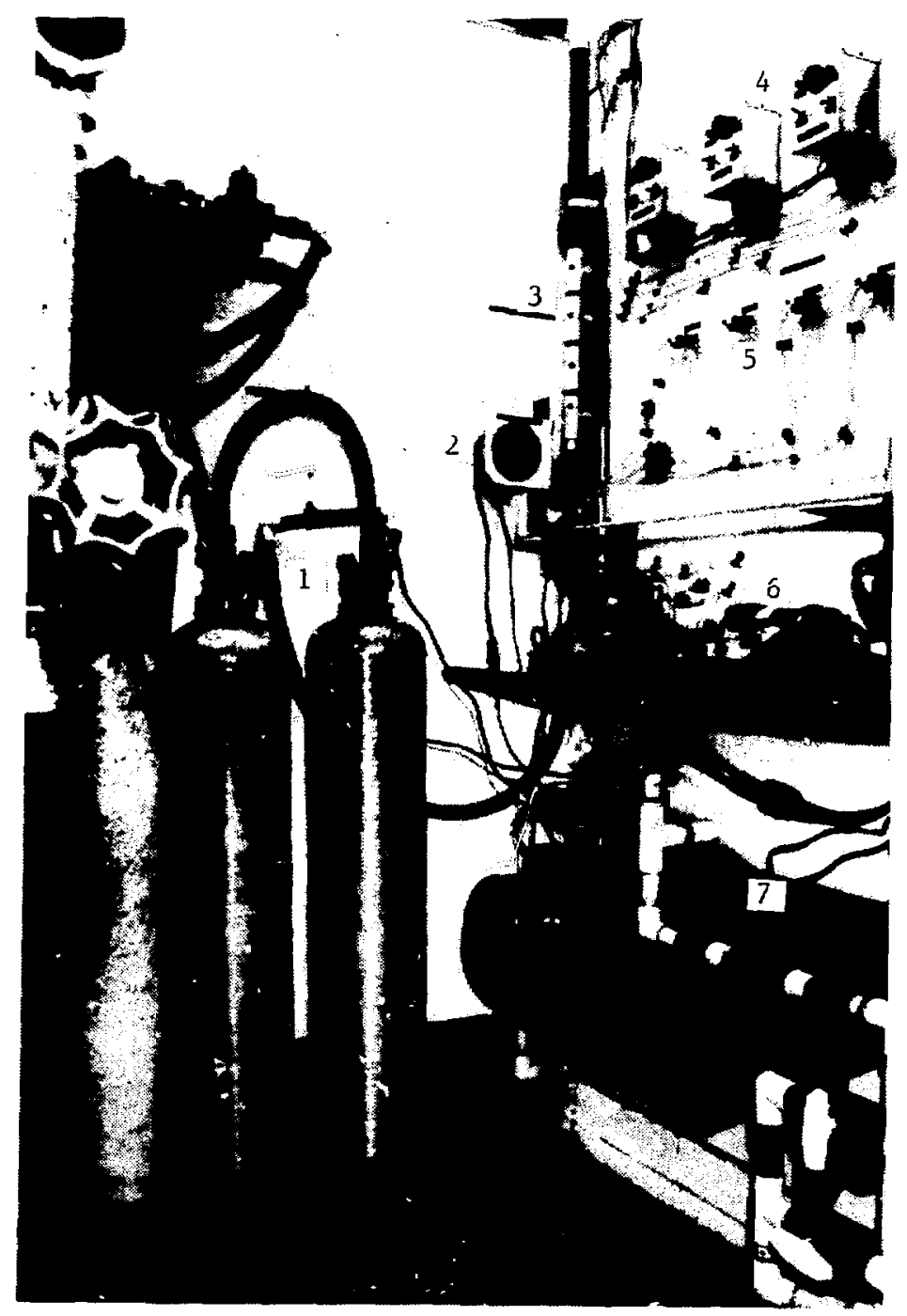

Fig. B.2 View of the inside of the control room.

1) Demineralizer System.

2) Leacharit Volume Meter.

3) Leachant Supply Manifold.

4) Liquid Level Monitors.

5) Leachate Sampling Ports.

6) Leachate Sampling Pumps.

7) Leachate Discharge Pump. 


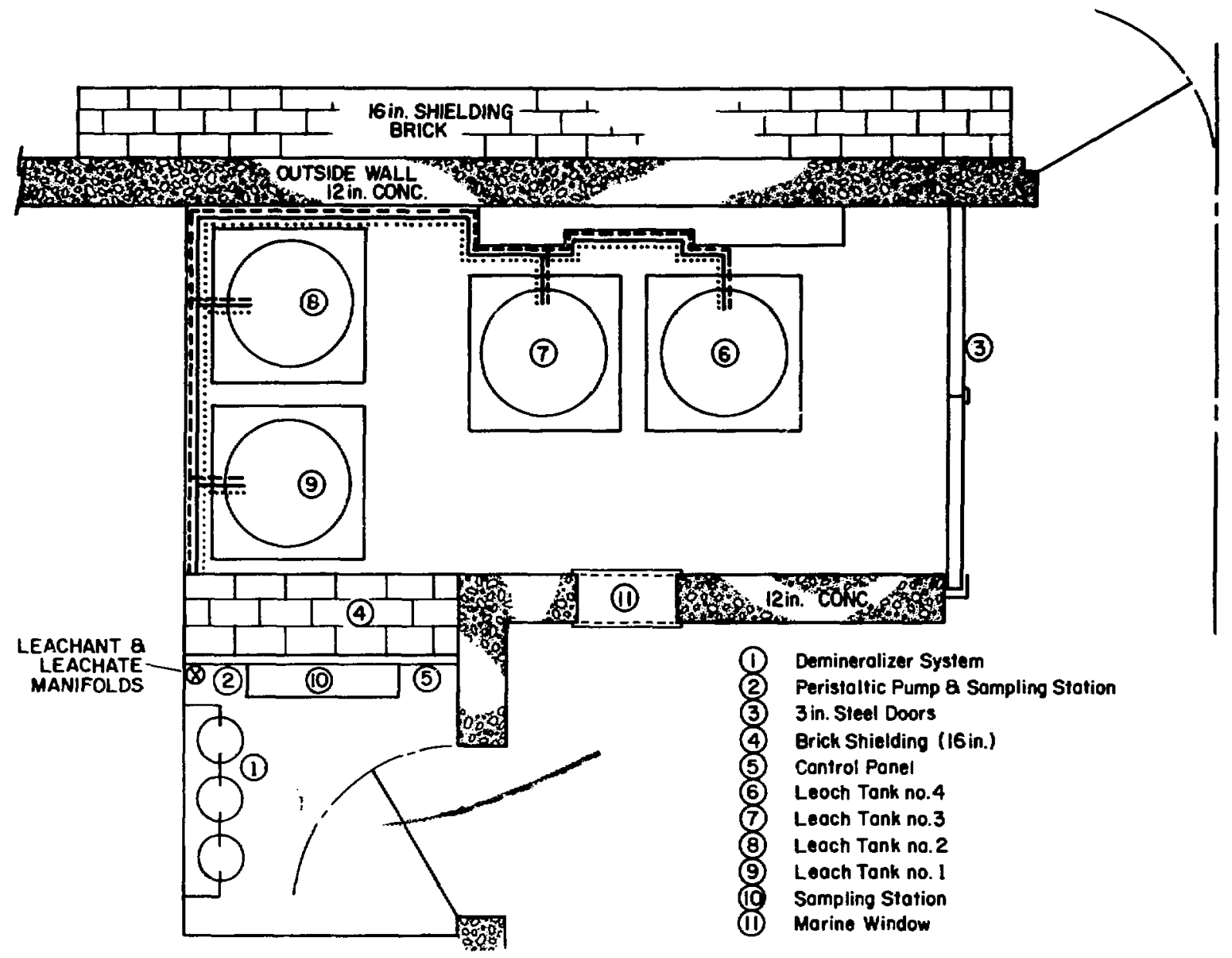

Fig. B.3 Layout of the Full-Scale Leaching Facility. 


\section{Ieaching Itanks.}

The leaching tanks are centrifugally cast reinforced fiberglass. The tanks measure 30 inches in diameter by 48 inches in height with a nominal wall thickness of 5/32 inches. They are equipped with tight fitting fiberglass covers to minimize evaporative losses. The size of the leaching tanks was determined so that each tank could accomodate the full-scale waste form and the required volume of leachant. The height to diameter ratio was selected so that the total waste form surface area would be immersed and approximately the same quantity of leachant would surround the surface of the waste form on each side.

Each leach tank is fitted with a stainless steel support stand designed to raise the waste form off the bottom, thus exposing the majority of the waste form's bottom surface to leachant. The tanks are positioned on dollies so they can be easily maneuvered despite their loaded weight of as much as 1400 lbs. The leaching tanks can be seen in Figure B.1.

Ieachant supoly system.

In order to supply the large volumes of high quality water necessary for the leaching of full-scale waste forms, a water purification system was installed in the control room area. The system consists of a 5 micron filter, an activated carbon adsorption column (for removal of organics) and two mixed bed resin deionizers connected in series. Water quality is monitored by warning lights for each of the ion exchange columns. The columns are replaced whenever the resistivity of the water falls below one megohm. The upstream column will be exhausted first. When it is replaced, the downstream column is rotated to the upstream position and the new column is placed in the downstream position. In addition, an 850 liter leachant storage reservoir was installed to handle the volume necessary for one complete leachant renewal cycle in the event of a failure of the water purification system. 
Deionized water flows from the purification system through a paddle wheel flow transducer to a leachant distribution manifold. By selecting the appropriate valve, any of the leaching tanks or the storage reservoir can be filied. The volume of deionized water delivered is displayed on a batch accumulator meter. This meter translates the electronic pulse signal generated by the paddle wheel into a flow volume in liters with an accuracy of \pm 28 of the reading at the calibrated flow rate.

From the supply manifold, leachant flows through $1 / 2$ inch I.D. PVC piping which is connected to a small section of flexible tygon tubing at the tank. These materials were chosen to minimize interaction with the leachant. Flow rates through the system average approximately 10 liters /minute. The layout of the leachant supply system can be seen in the schematic diagram shown in Figure B.4

\section{Leachate Sampling System.}

Aliquots for leachate analysis are taken remotely by means of the leachate sampling system. This system consists of two dual channel variable speed peristaltic pumps, 5/16 inch I.D. tygon tubing, and polypropylene three-way stopcock valves. Each tank has a separate sampling channel. Tubing is arranged in a closed loop to permit circulation of the leachate prior to sampling. The peristaltic pumps can be operated in reverse to allow purging and flushing of the sampling lines, minimizing the cross-contamination of samples with leachants from previous samples. With pumps operating at full speed (600 RPM) the maximum flow rate is 2280 milliliters/minute.

\section{Leachate Discharge_System.}

At the end of each leaching interval and after the leachate sample has been taken, the remaining leachate must be drained and fresh leachate supplied. The leachate discharge system was designed to drain the tanks quickly (less than 20 minutes on average), thus minimizing the time that the leaching specimens are exposed to air. 


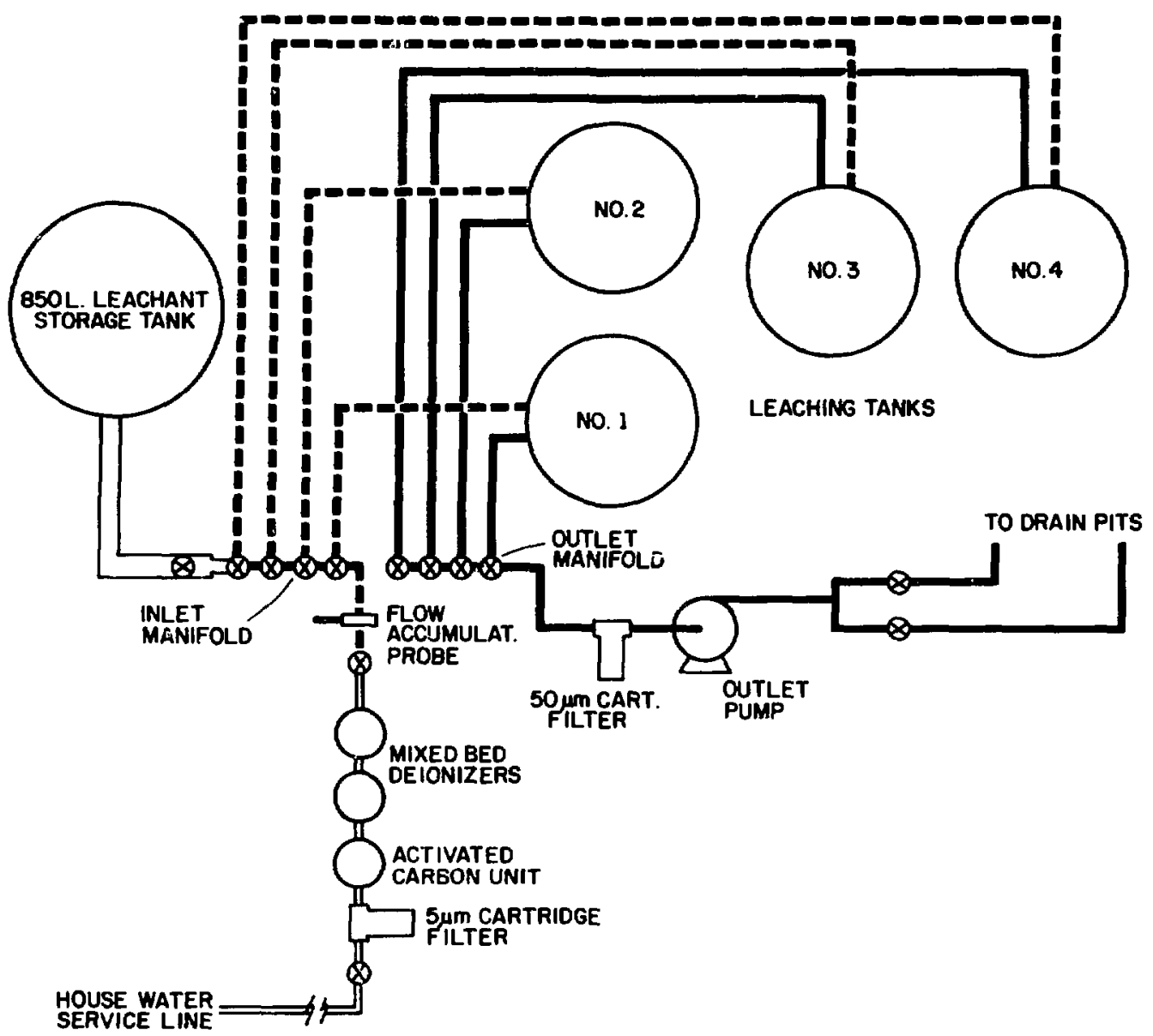

Fig. B.4 Schematic view of the leachant supply and leachate discharge systems. 
Leachate is drawn from the tanks by a positive displacement flexible impeller pump, powered by a 1 HP motor operated at 1160 RPM. Contained in the tank is a suction riser pipe equipped with a one-way foot valve to prevent reverse flow and a roughing screen to prevent large particles from entering. The leachate flows from the tanks through $3 / 4$ inch I.D. PVC piping to a discharge manifold which enables selection of any combination of tanks to be drained concurrently. From the manifold, the leachate flows through a 50 micron filter which screens out fine particulate matter which may be abrasive to the pump. As pump failure may result from dry running, a flow sensor safety switch is installed to automatically shut off the pump motor. From the discharge side of the pump, leachate flows to two drain pits, a temporary hold up tank, and then on to the building's radioactive liquid waste system. The leachate discharge system is shown schematically in Figure B.4

\section{Safety Features.}

In the event that the operator fails to shut off the supply of fresh leachant, a liquid level sensor installed in each tank provides an audible warning signal prior to overflow of the tanks. Level sensors also alert the operator when tanks are empty. If a leak develops in one or more tanks, the leachate would flow down the slightly graded floor and empty into the drain pits located below. A 6 inch stainless steel curb located along the perimeter of the experimental facility is designed to retain any liquid spill. 


\section{Introduction.}

Prior to the initiation of the full-scale leaching experiment, the waste forms were removed from their shipping containers. This was done to allow the testing of bare waste forms in accordance with accepted leaching practice.

\section{Facility Description.}

The facility utilized for the decanning operation was a preparations area adjacent to a BNL metallurgical hot cell. A photograph of this facility is shown in Figure C.l. This location provided adequate radiation shielding, yet allowed health physicists, support personnel and observers to view the operation from the outside. During the decanning procedure, the roon was closed off and placed under slight negative pressure to minimize the possibility of release of airborne contaminants. All air exiting the facility was filtered through a high efficiency particulate air (HEPA) filter. Radiation levels were monitored by the use of GM counters and continuous air sampling monitors.

In order to reduce personnel exposure during the decanning operation, waste form packages were stored within the heavily shielded adjoining hot cell, and removed as needed. A 3 ton overhead crane was used to lift and lower the waste forms during the decanning procedure.

Personnel involved in the decanning operation wore full protective clothing and breathing apparatus equipped with HEPA filtration cannisters. Radiation doses were monitored by pocket dosimeters and film badges.

\section{Procedure.}

The procedure for the removal of waste forme from their drums varied, depending upon the solidification process utilized to package them. 
1) Series 1 and 2 waste forms: These waste forms are portland cement mixed within closed head, 55 gallon Dor 17-C drums by means of an end-over-end drum tumbler. Consequently the solidified waste forms assumed the same shape as the drums, requiring that the containers be cut off. In several trials using non-radioactive simulated waste forms, it was demonstrated that the safest and most efficient container removal method was to use an oxygen-acetylene cutting torch. Furthermore, it was shown that with proper manipulation of the cutting torch, the waste form would sustain no damage as a result of this procedure.

Each drum, in turn, was laid on its side, and four continuous cuts were made (top, two sides, and bottom). The drum was pried off in two sections. The waste form was lifted by overhead crane secured to the eyehook solidified within the form to facilitate handling. The leaching tank was wheeled beneath the waste form which was then lowered slowly into place. Photographs depicting the decanning procedure for series 1 and 2 waste forms taken during a practice trial using non-radioactive simulated waste forms are shown in Figures C.1-C.4.

2) Series 4 waste forms: This waste form is masonry cement prepared in an in-line mixing system. The waste container was an open head 55 gallon DoT-17C drum with polyethylene liner. Since the solidified waste did not come in contact with the inside of the drum, the waste form (in the polyethylene liner) was easily removed from the 55 gallon drum when lifted by an overhead crane. The polyethylene liner was then cut away from the waste form using a utility knife and the waste form was lowered into the leaching tank.

3) Series 6 and 7 waste forms: These vinyl ester-styrene waste forms were mixed using an in-container system. As in series 4 waste forms, the waste containers were 55 gallon DOT 17-C drums with polyethylene liners. However, due to the interference caused by binder materials which lodged between the drum and liner, the waste form and liner would not slip from the drum. This necessitated cutting the drum to provide the additional clearance needed to separate it from the waste form in the polyethylene liner. 
Series 6 and 7 waste forms did not contain eye hooks and therefore required another method for handling and placement in the leaching tanks. For this purpose, the waste form stand (described previously and seen in Figure C.5) was modified with $1 / 4$ inch diameter stainless steel cables to form a lifting rig. As seen in Figures C.6-C.11, this assembly was placed around the drum (after the cover was removed) and supported the waste form as the drum was removed from above. Figure C.10 shows the polyethylene liner being cut from the waste form using a utility knife. The waste form and support stand were lowered into the leaching tank as shown in Figure C.ll. 


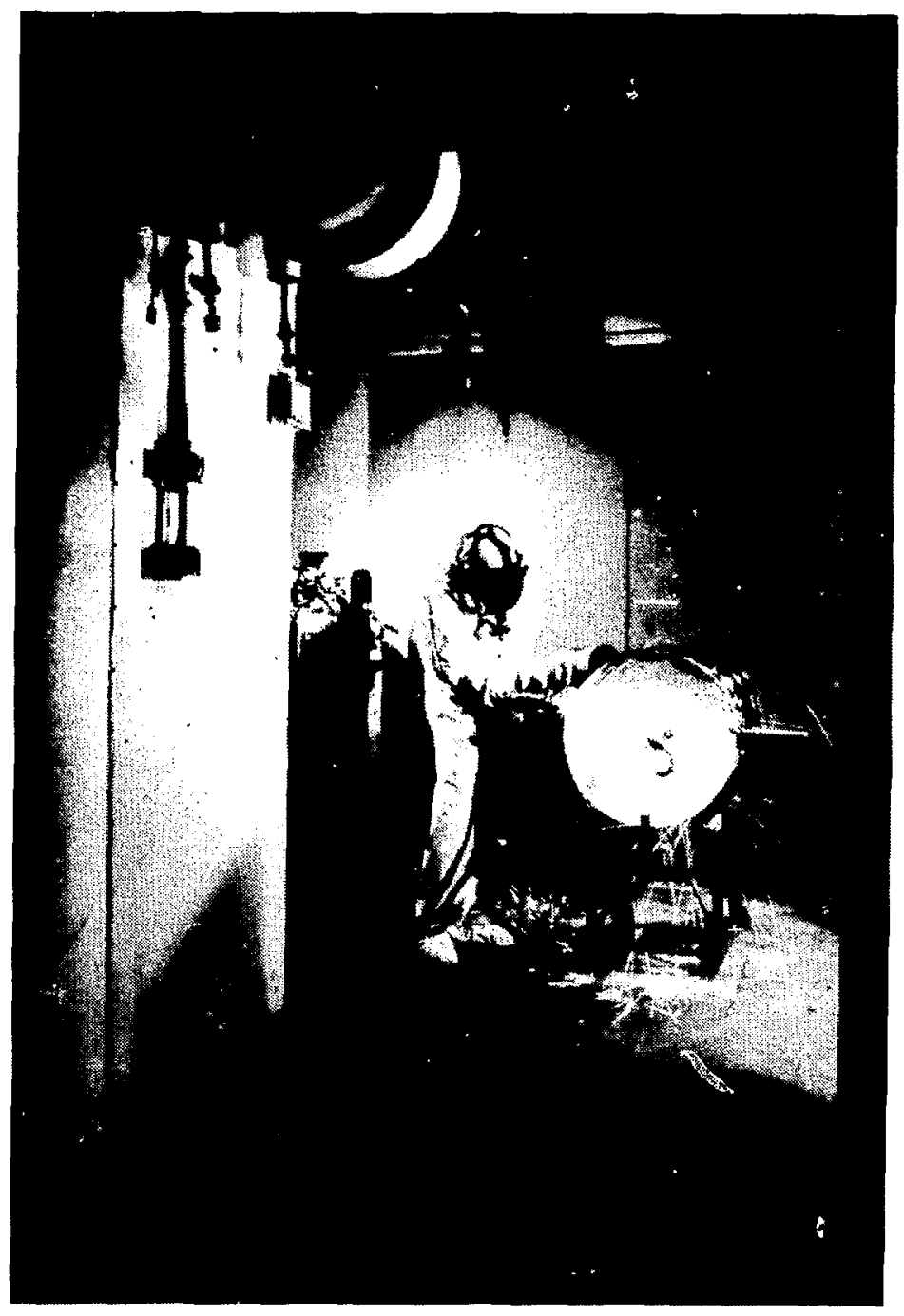

Fig. C.1 Decanning operation for Series 1 and 2 waste forms performed on simulated waste packages. During the actual operation, the area was sealed off to prevent dispersion of contamination, thus preventing the taking of photos at this time. In this photo the 55 gallon DOT $17 \mathrm{C}$ drum is being cut with an oxyacetylene torch. 


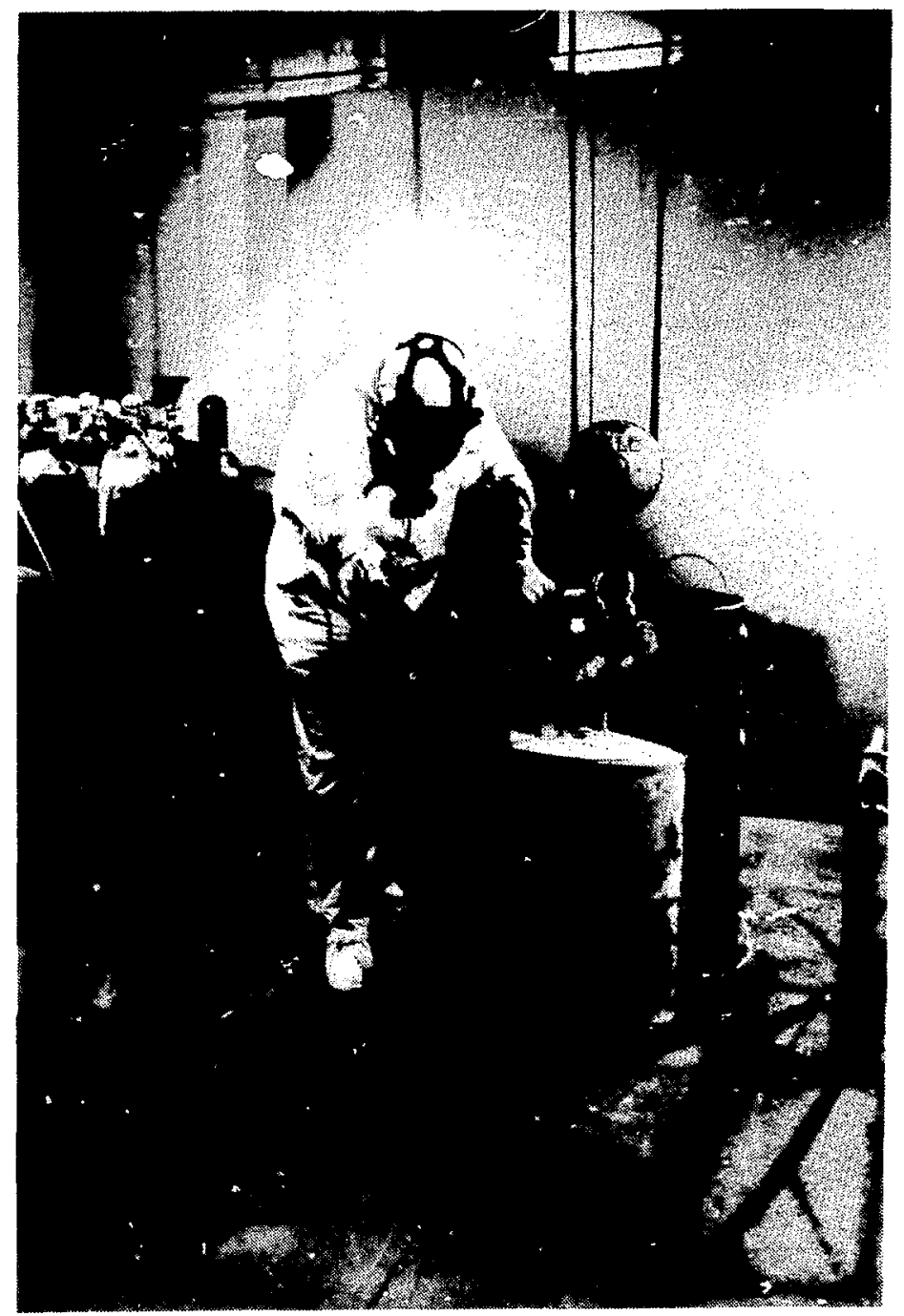

Fig. C.2 After cutting, the drum is removed from waste form. 


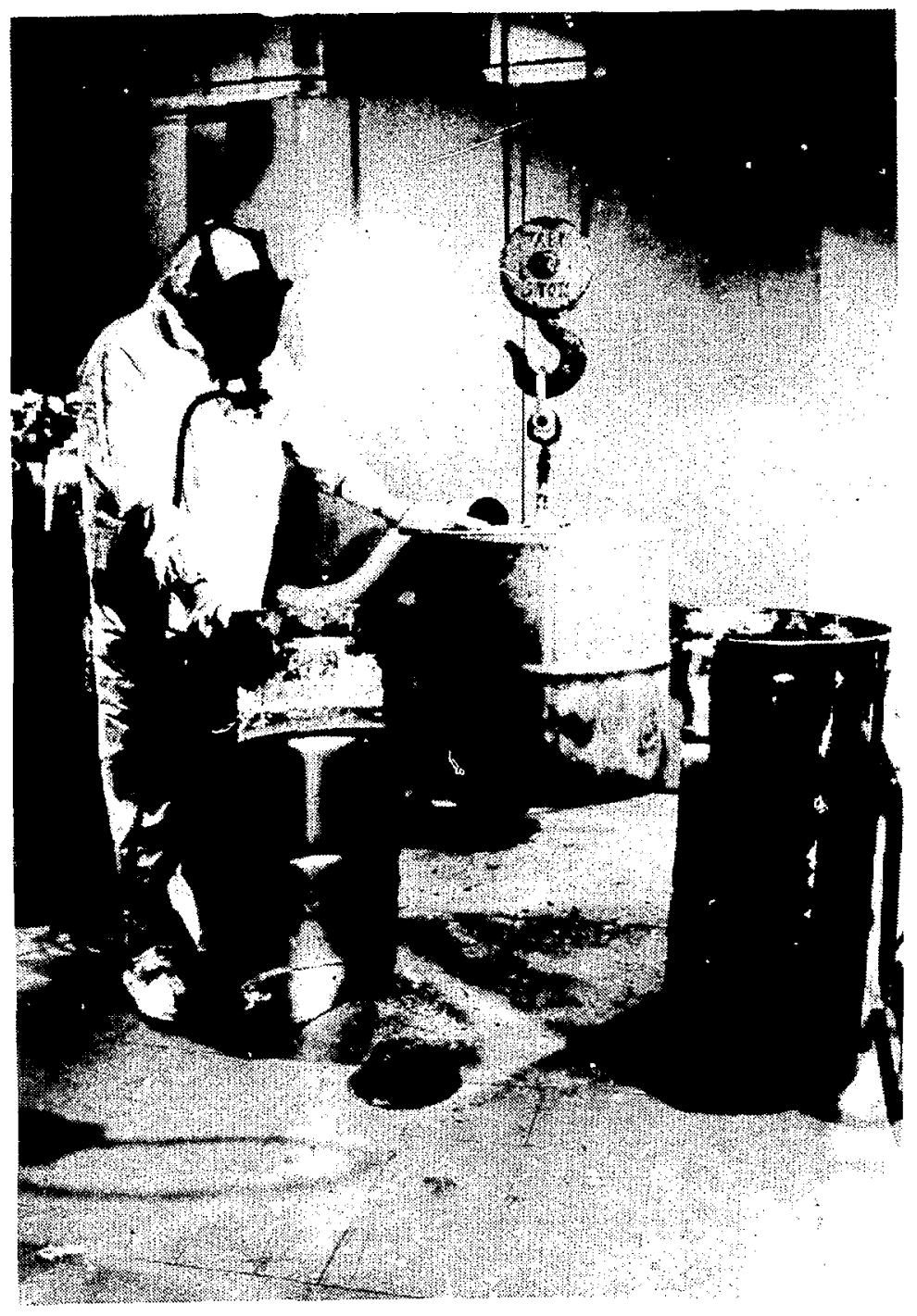

Fig. C.3 Waste form is lifted by means of an overhead crane and an eyehook which has been embedded in the waste form. 


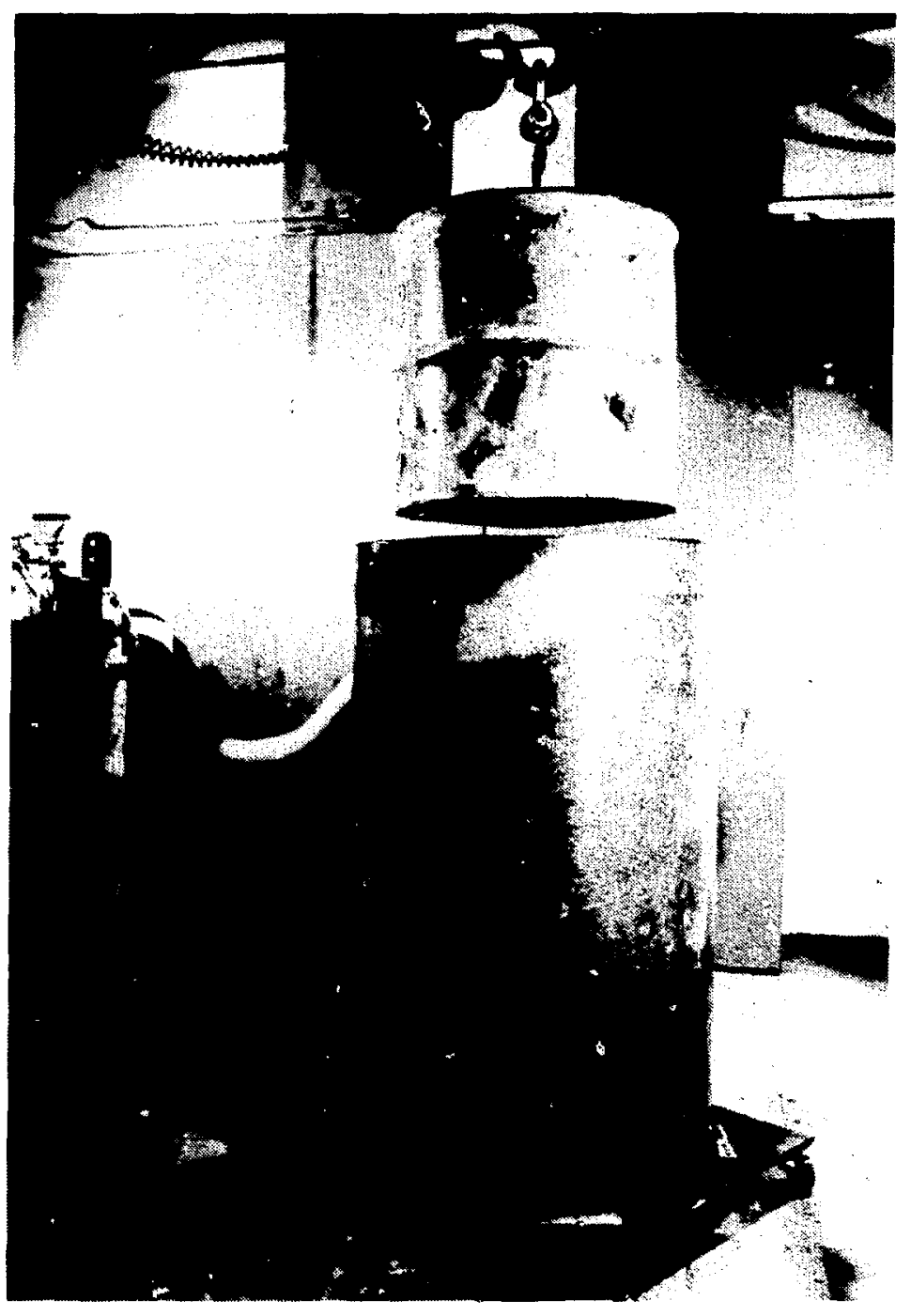

Fig. C. 4 Waste form is lowered into Teaching vessel. The support stand is in place inside tank. 


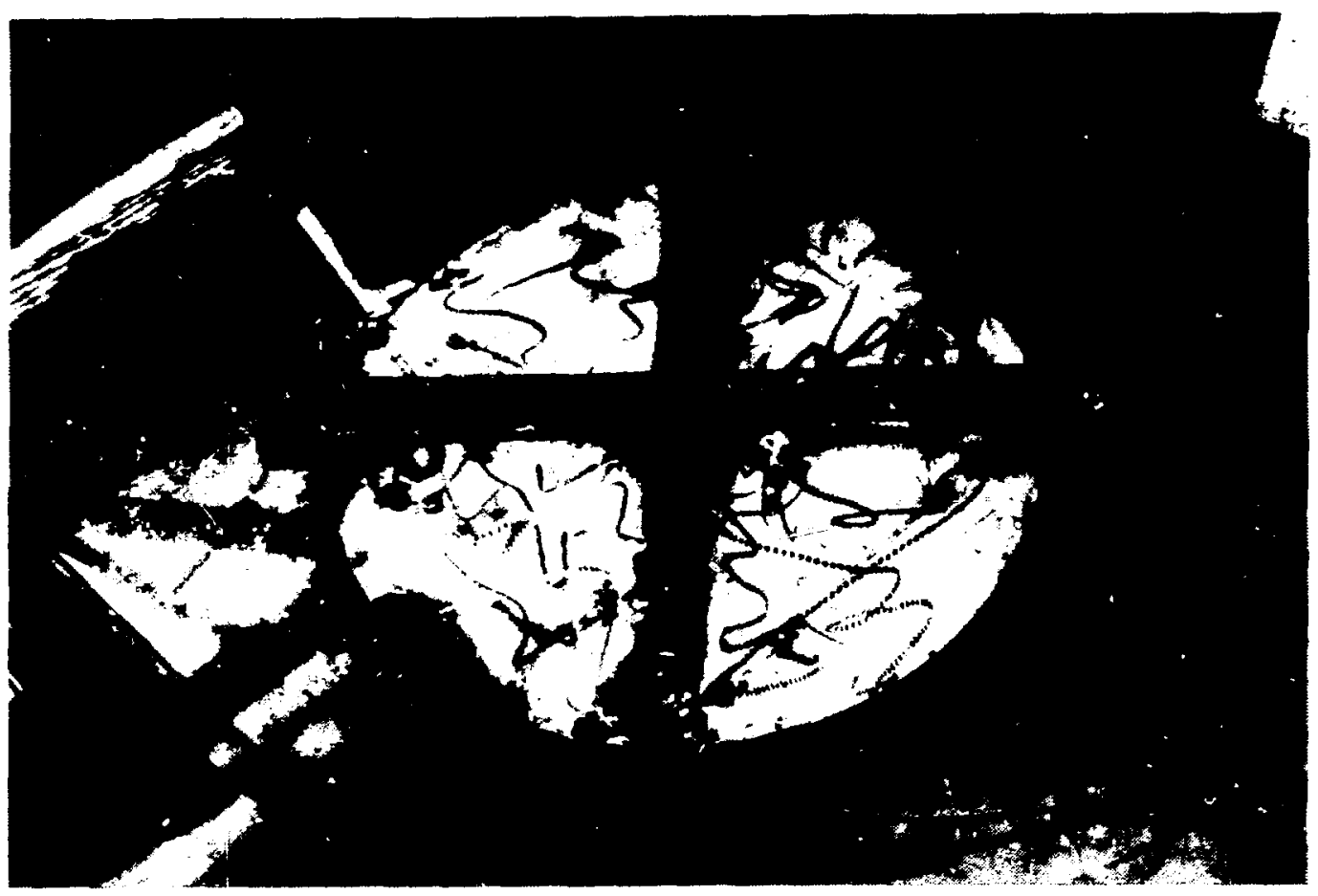

Fig. C.5 Waste form stand modified to form a lifting rig for the vinyl ester-styrene Series 6 and 7 waste forms. 


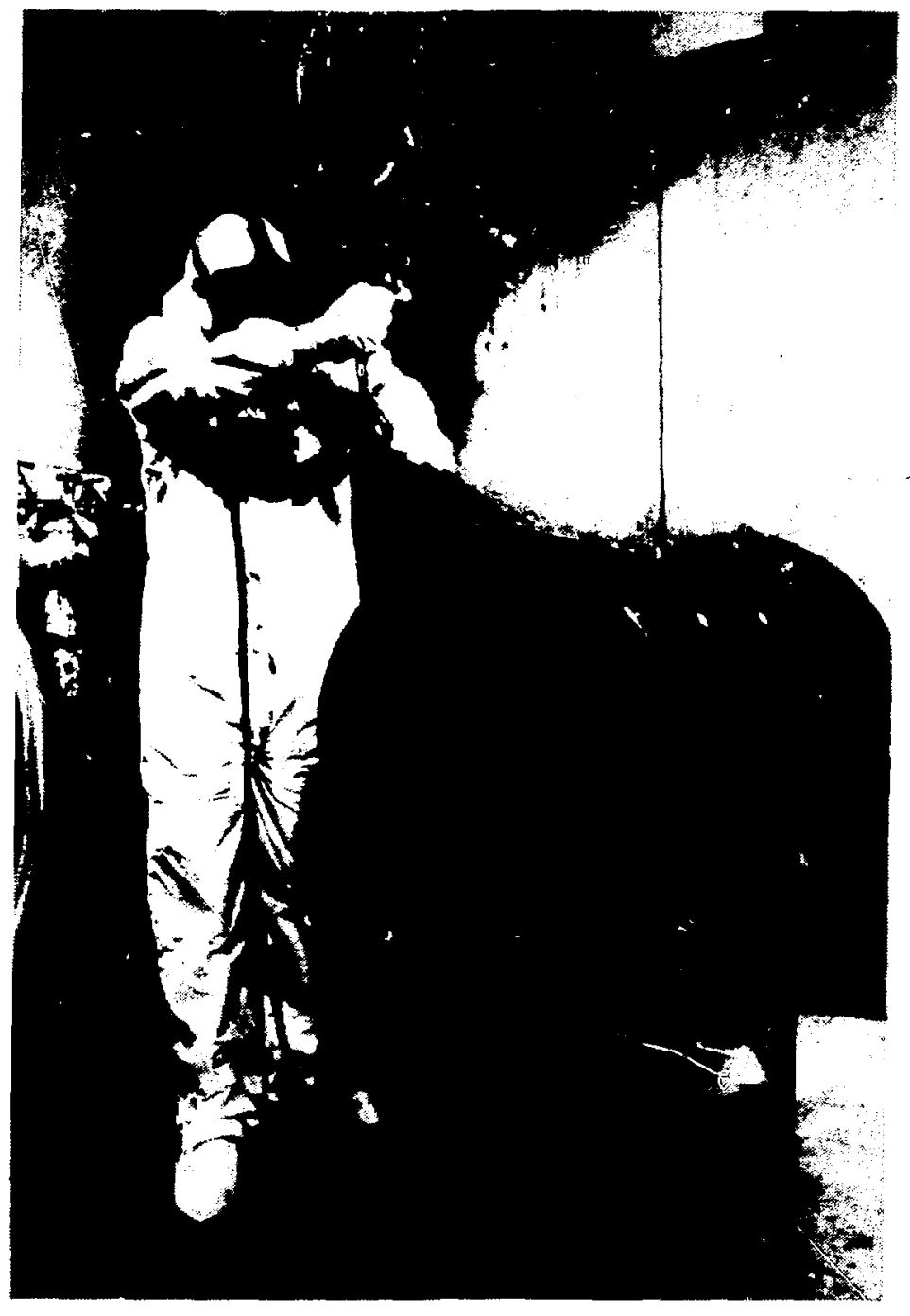

Fig. C.6 Removal of non-radioactive simulated Series 6 waste form from the 55 gallon drum. The support stand/lifting rig is placed around drum after the cover has been removed. 


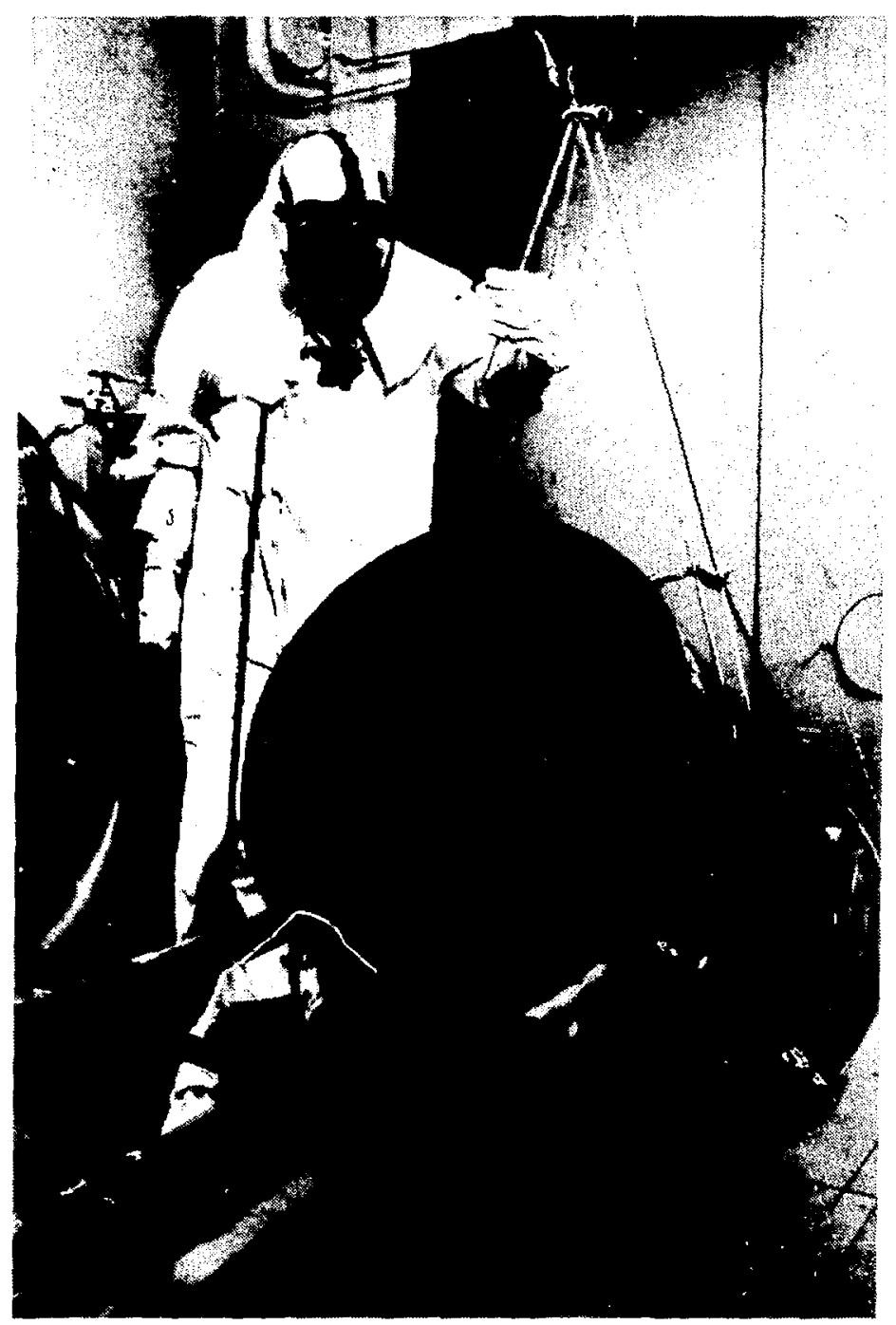

Fig. C.7 Upending drum. 


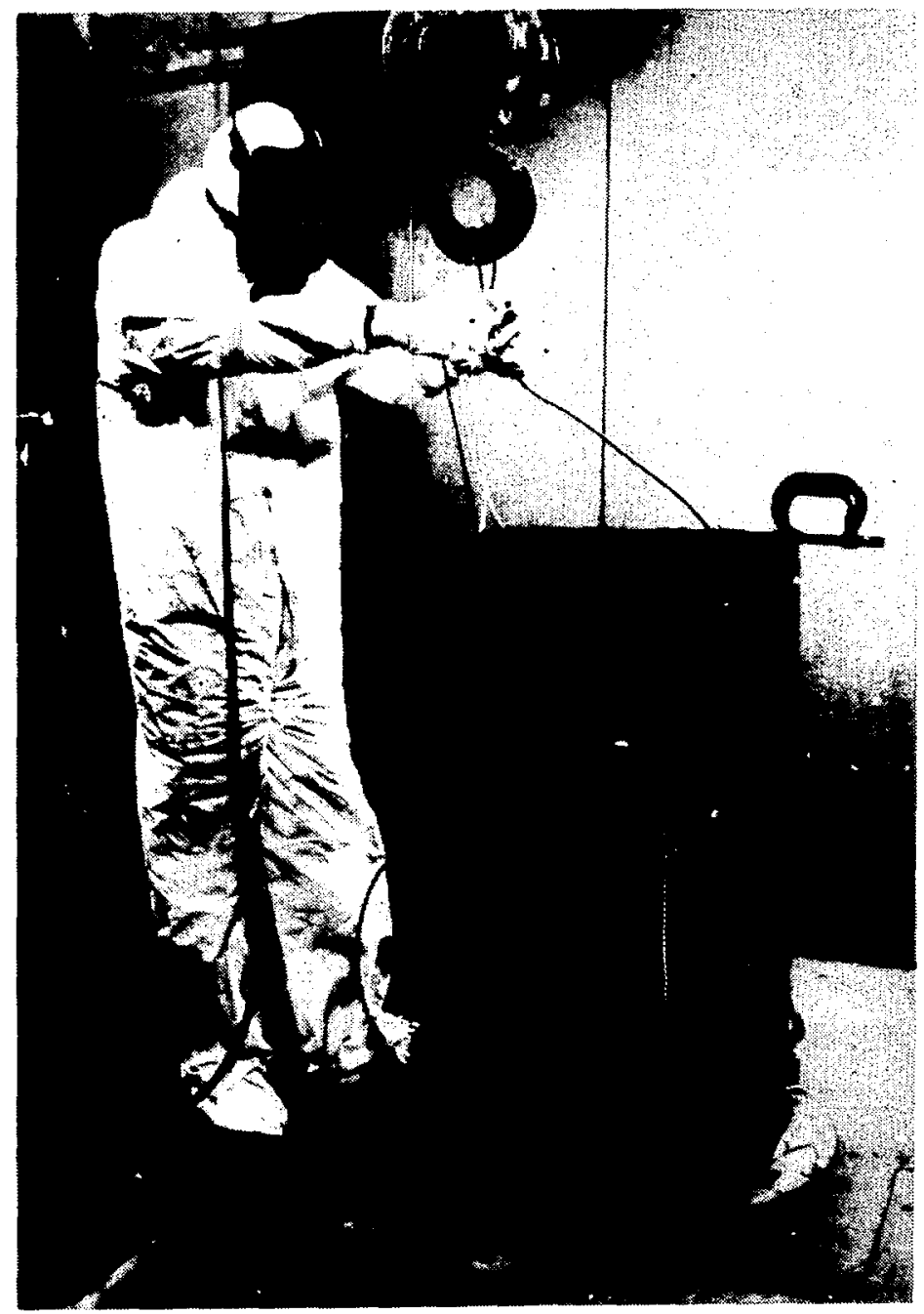

Fig. C.8 Preparing the 55 gallon drum for removal. 


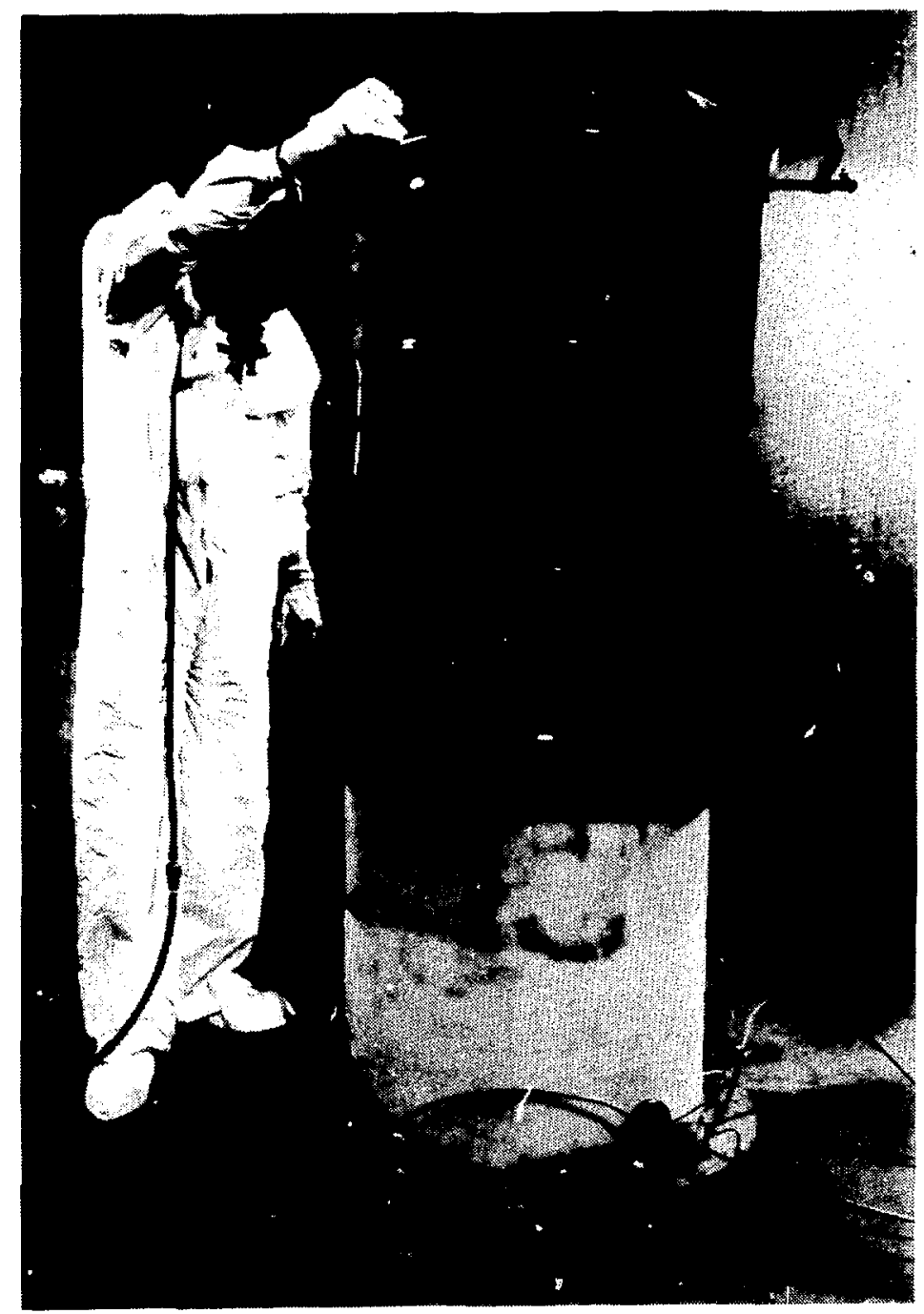

Fig. C.9 Removing the drum from the waste form. 


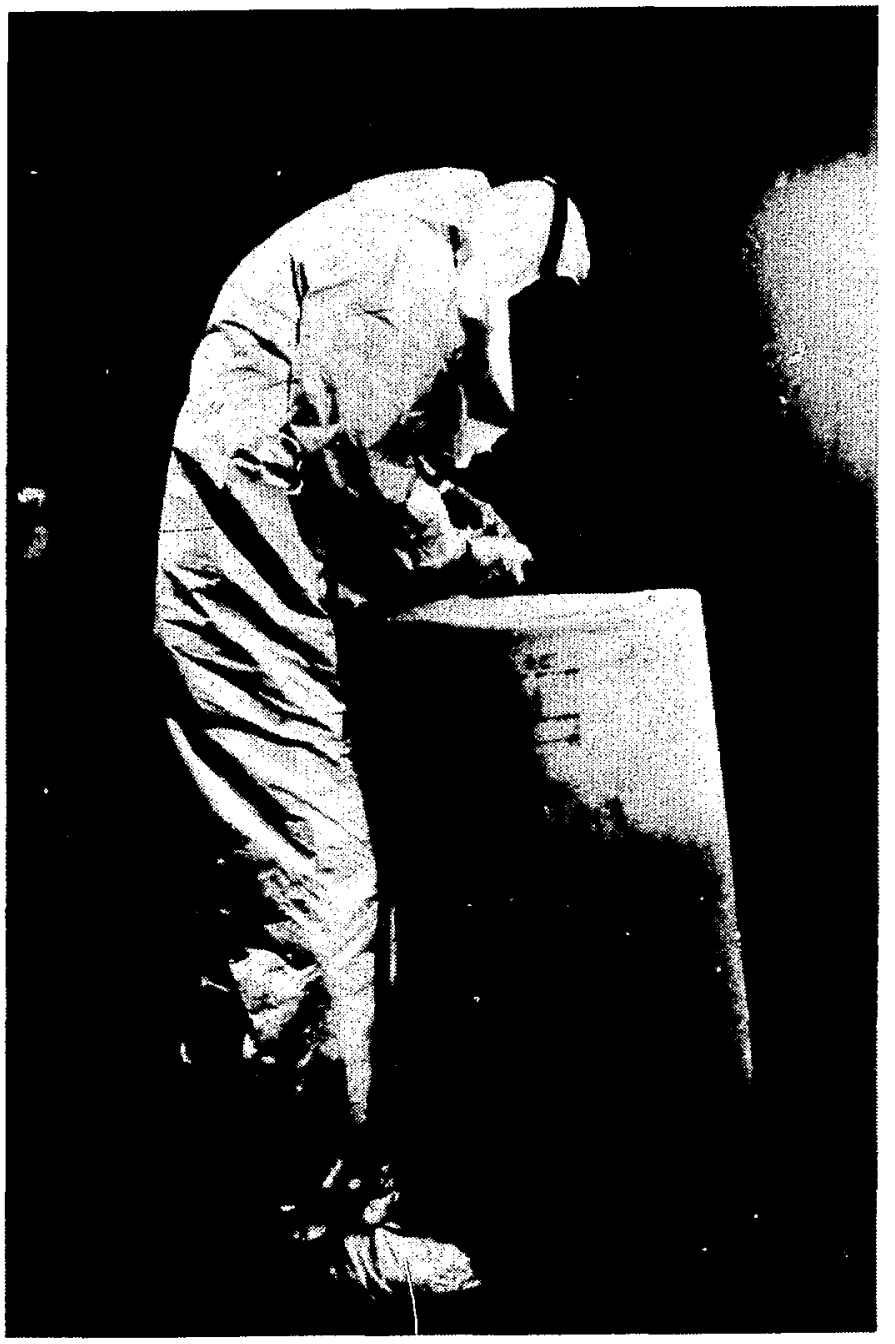

Fig. C.10 The polyethylene liner is removed by cutting with a utility knife. 


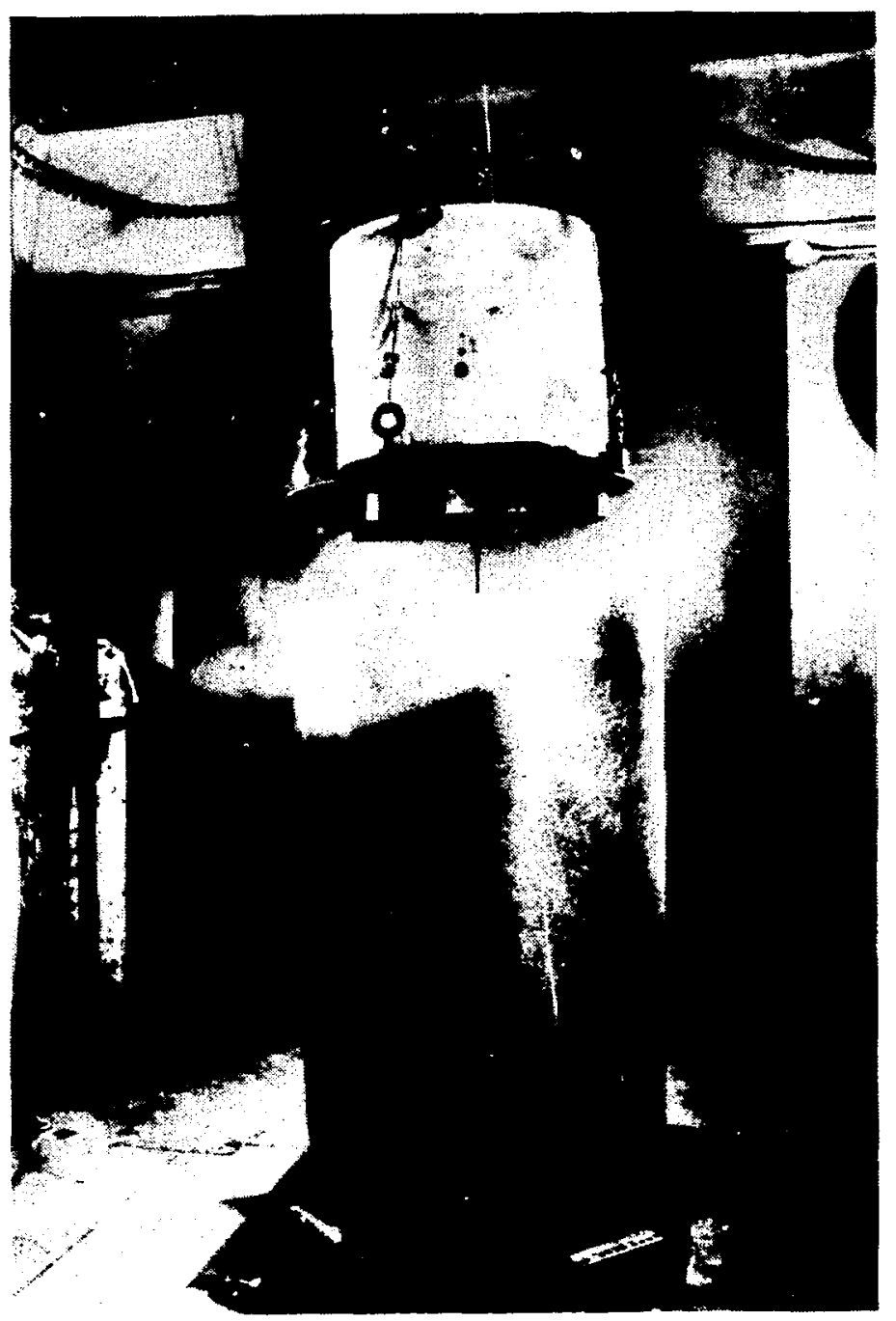

Fig. C.11 Lowering the simulated Series 6 waste form and support stand into the leaching tank. 